\title{
Antiphospholipid Antibodies Promote Tissue Factor-Dependent Angiogenic Switch and Tumor Progression
}

\author{
Yuan-Yuan Wu, ${ }^{*}$ Andrew V. Nguyen, ${ }^{\dagger}$ Xiao-Xuan Wu, ${ }^{\star}$ Mingyu Loh, ${ }^{\dagger}$ Michelle Vu, ${ }^{\ddagger}$ Yiyu Zou, ${ }^{\S}$ Qiang Liu, ${ }^{*}$ Peng Guo,
} Yanhua Wang, ${ }^{*}$ Leslie L. Montgomery, ${ }^{\|}$Amos Orlofsky, ${ }^{*}$ Jacob H. Rand, ${ }^{*}$ and Elaine Y. Lin

From the Department of Pathology, * Montefiore Medical Center, the Departments of Medicine/Oncology $y^{\S}$ and Surgery, "and the Analytical Imaging Facility, Einstein Cancer Center, Albert Einstein College of Medicine, New York, New York; the Department of Biological Sciences and Geology, ${ }^{\dagger}$ The City University of New York, Queensborough Community College, Bayside, New York; and the Department of Psychology, ${ }^{\ddagger}$ Boston College, Boston, Massachusetts

\author{
Accepted for publication \\ July 29, 2014. \\ Address correspondence to \\ Elaine Y. Lin, M.D., Ph.D., \\ Cell, Developmental, and Can- \\ cer Biology, Oregon Health and \\ Science University, 3181 SW \\ Sam Jackson Park Rd., Port- \\ land, Oregon 97239. E-mail: \\ line@ohsu.edu.
}

\begin{abstract}
Progression to an angiogenic state is a critical event in tumor development, yet few patient characteristics have been identified that can be mechanistically linked to this transition. Antiphospholipid autoantibodies (aPLs) are prevalent in many human cancers and can elicit proangiogenic expression in several cell types, but their role in tumor biology is unknown. Herein, we observed that the elevation of circulating aPLs among breast cancer patients is specifically associated with invasive-stage tumors. By using multiple in vivo models of breast cancer, we demonstrated that aPL-positive IgG from patients with autoimmune disease rapidly accelerates tumor angiogenesis and consequent tumor progression, particularly in slow-growing avascular tumors. The action of aPLs was local to the tumor site and elicited leukocytic infiltration and tumor invasion. Tumor cells treated with aPL-positive IgG expressed multiple proangiogenic genes, including vascular endothelial growth factor, tissue factor (TF), and colony-stimulating factor 1 . Knockdown and neutralization studies demonstrated that the effects of aPLs on tumor angiogenesis and growth were dependent on tumor cell-derived TF. Tumor-derived TF was essential for the development of pericyte coverage of tumor microvessels and aPL-induced tumor cell expression of chemokine ligand 2, a mediator of pericyte recruitment. These findings identify antiphospholipid autoantibodies as a potential patient-specific host factor promoting the transition of indolent tumors to an angiogenic malignant state through a TF-mediated pathogenic mechanism. (Am J Pathol 2014, 184: 3359-3375; http://dx.doi.org/10.1016/j.ajpath.2014.07.027)
\end{abstract}

The identification of mechanisms that trigger the malignant transition of indolent, avascular tumors is an important goal for cancer prevention and treatment. The avascular state may occur as either an early stage in primary tumor development or minimal residual disease after treatment. ${ }^{1}$ The transition of avascular tumors to a malignant state depends on the induction of angiogenesis (angiogenic switch), ${ }^{1}$ but the mechanisms that drive this transition have not been well defined. It would be especially valuable to elucidate patient-specific host factors that modulate tumor angiogenesis and progression, but few such factors that are assessable in patients have been identified.

The antiphospholipid antibodies (aPLs) are a class of autoantibodies that recognize complexes of phospholipid- binding proteins bound to anionic phospholipids on the cell surface. ${ }^{2}$ Anionic phospholipids are absent from the surface of most cells but translocate to the surface on activation of endothelial cells, monocytes, and platelets, as well as during apoptosis and malignant transformation. ${ }^{3-5}$ The incidence of aPLs in the general population is approximately $1 \%$ to $5 \%$. $^{6}$ Chronic aPL elevation can lead to a thrombogenic state

\footnotetext{
Supported by Idea Award Collaborative Option: BC094408 from the Department of Defense [US Army Medical Research and Material Command (MRAMC) and Congressionally Directed Medical Research Programs (CDMRP)] (to E.Y.L. and J.H.R.).

Disclosures: None declared.

Current address of E.Y.L., Cell, Developmental, and Cancer Biology, Oregon Health and Science University, Portland, OR.
} 
known as antiphospholipid syndrome (APS), ${ }^{2,7}$ and aPL elevation also can occur transiently in association with viral and several other infections ${ }^{8}$ as well as in patients with other autoimmune disorders, such as lupus or rheumatoid arthritis. Numerous studies have shown a significantly increased frequency of circulating aPLs in cancer across multiple tumor types, compared with matched controls, with incidence generally $15 \%$ to $25 \% .^{10-12}$ Because the linkage of aPLs to coagulation is well-known, studies of the pathological implications of aPLs in cancer have focused on thromboembolic disorders, a common complication in many malignancies. ${ }^{11}$ Although comparatively few studies have examined aPLs as a potential risk factor for cancer development or progression, studies with relatively short-time follow-up found an association between aPLs and non-coagulation-related cancer mortality, ${ }^{13}$ and aPL-positive patients experienced a higher than expected frequency of non-Hodgkin lymphoma. ${ }^{14}$

The potential for aPL as an angiogenic factor has long been evident. aPLs can induce the expression of vascular endothelial growth factor (VEGF) and tissue factor (TF) in monocytes and endothelial cells. ${ }^{15-18} \mathrm{TF}$, a central factor in coagulation cascade, can stimulate angiogenesis via either procoagulant function and platelet activation or, alternatively, the direct activation of protease-activated receptor-2 (PAR2; alias coagulation factor II receptor-like 1) and proangiogenic signaling in endothelial cells. ${ }^{19,20}$ Many tumor cells produce TF, and tumor cell-derived TF has been shown to promote tumor progression. ${ }^{20,21}$ Despite these studies, the effects of aPLs from patients on tumor cells and angiogenesis have not been previously examined. In this study, we present evidence that aPL activates proangiogenic gene expression in breast cancer cells, induces TF-dependent vascularization in small, slow-growing avascular tumors, and promotes tumor progression in multiple mouse models of breast cancer. Collectively, these findings indicate a potential protumor role for these autoantibodies.

\section{Materials and Methods}

\section{Mice}

All procedures were approved by the Institutional Animal Care and Use Committees of Albert Einstein College of Medicine (Einstein; New York, NY) and by the Animal Care and Use Review Office (US Department of Defense). All mice were housed in the pathogen-free barrier facility at Einstein. Nude mice in NCr background were obtained from Taconic Farms (Albany, New York) and bred at Einstein. Polyoma virus middle $\mathrm{T}$ antigen (PyMT) mice were kindly provided by Dr. Jeffrey W. Pollard (Albert Einstein College of Medicine, Bronx, NY) and backcrossed to mice with C57BL/6 background for $>10$ generations.

\section{Cell Lines}

MDA-MB-436 breast cancer cells were obtained from the National Cancer Institute Tumor Repository (Frederick,
MD). The breast cancer lines MDA-MB-468 and MDAMB-231, as well as the prostate cancer cell line PC3, were obtained from ATCC (Manassas, VA). Cells were cultured according to the supplier's recommendations.

\section{TF Knockdown}

Four TF-knockdown shRNA constructs were selected from the shRNA library of The RNAi Consortium (vector backbone: pGIPZ). The target regions for three of the shRNA sequences, TFKD321 (5'-CTTCTATGGTTGACATTGT$\left.3^{\prime}\right)$, TFKD322 (5'-CTGTTATTACCATTAGCAT-3'), and TFKD $323\left(5^{\prime}\right.$-TGGAGCTACTGCAAATGCT- $\left.3^{\prime}\right)$, were in the $3^{\prime}$ untranslated region of the TF (F3) gene; a fourth, 5'TFKD324 (5'-AAGTCTACACTGTTCAAAT-3'), was within the coding sequence of exon 2 . The lentiviral expression vector carried turbo-green fluorescent protein (GFP). Viruscarrying turbo-GFP alone was used as a positive control for transfection. Selection and lentiviral packaging of the constructs, along with an empty vector control, were performed by the shRNA Core Facility at Einstein. Lentivirus carrying the above constructs was transfected into human breast cancer cells following the GIPZ lentiviral shRNA technical manual from Thermo Scientific (Waltham, MA). Lentivirally transduced cells were selected in $6 \mu \mathrm{g} / \mathrm{mL}$ of puromycin for 7 days, after which $>90 \%$ of cells were GFP positive.

\section{Human Breast Cancer Samples}

Procedures using human samples were approved by the Institutional Review Board of Montefiore Medical Center (MMC)/ Einstein (09-06-190X). Residual sera, collected for preoperational tests from patients with abnormal breast mass at MMC, were examined for aPL titer (described below). The diagnosis and staging of breast lesions was performed by the surgical pathologists (Y.W. and other on-service pathologists) at MMC.

\section{Determination of aPL Titer}

Serum samples were assayed for aPL by the Immunodiagnostic Laboratory at MMC using a commercial ELISA kit from BIO-RAD (Hercules, CA). The assays included the following: anti-cardiolipin (IgM, IgG), anti- $\beta-2$ glycoprotein I (IgM, IgG, IgA), and anti-phosphatidylserine (aPS; IgM, IgG). Samples with medium/high titer, according to criteria established by international consensus, ${ }^{22}$ were classified as aPL positive.

\section{IgG Samples}

Plasma samples, obtained from two patients with APS, were designated as aPL\#1 and aPL\#3. These samples, as well those from five healthy donors (referred to as control $\mathrm{IgG}$ herein), were prepared from discard plasma samples obtained during diagnostic or other unrelated clinical procedures (Institutional Review Board number 09-06-190X). Serum was prepared from 
plasma by incubation with $1 \mathrm{U} / \mathrm{mL}$ human thrombin (SigmaAldrich, St. Louis, MO) at $37^{\circ} \mathrm{C}$ for 30 minutes, followed by clot removal. Total IgG was isolated, as described previously, ${ }^{23}$ using protein $\mathrm{G}$ Sepharose 4 , according to the manufacturer's recommended procedure (Amersham Pharmacia Biotech, Piscataway, NJ). Purified IgGs were dialyzed against phosphatebuffered saline (PBS), and the protein concentration was determined by absorbance at $280 \mathrm{~nm}$. A third sample of patient IgG with elevated aPL was obtained from LifeSpan BioSciences, Inc. (Seattle, WA) and designated aPL\#2. aPL titers of all samples were determined as described above. IgGs from the three patients are referred to collectively as $\mathrm{aPL}^{+} \mathrm{IgGs}$.

Affinity-purified aPS/anti-cardiolipin IgG was prepared by modification of a published method. ${ }^{24}$ Briefly, phosphatidylserine and cardiolipin (Sigma-Aldrich) in 100\% ethanol were mixed at a 2:3 molar ratio in a $50-\mathrm{mL}$ conical tube, dried, and suspended in Tris- $\mathrm{HCl}$ buffer ( $\mathrm{pH}$ 7.4). The tube was rotated at $37^{\circ} \mathrm{C}$ for 1 hour for liposome formation. aPL\#1 serum was added, and the tube was rotated for 2 hours. Liposomes were then pelleted, washed with the same buffer, and resuspended in $20 \mathrm{mmol} / \mathrm{L}$ phosphate buffer containing $0.1 \%$ Tween 20 (pH 7.4). The affinity-purified IgGs were then isolated with protein $G$ Sepharose 4 (Amersham Pharmacia Biotech). Affinity-purified $\mathrm{IgG}$ was approximately 14 -fold enriched in aPL titer relative to unpurified IgG, as assessed by aPS activity.

\section{Controls for Endotoxin Effects}

IgGs from patients or normal controls were treated with Detoxi-Gel Endotoxin Removing Gel (Thermo Scientific, Rockford, IL) following the manufacturer's recommended protocol. No significant differences were observed in the effect of human IgGs on tumor cells' proangiogenic gene expression nor tumor growth and leukocytic infiltration in xenografted breast model between Detoxi-Gel endotoxintreated and untreated human IgGs.

\section{Cell Viability and Proliferation Assays}

MDA-MB-436 cancer cells $\left(1 \times 10^{5}\right.$ per well $)$ were plated in 96-well plates in RPMI 1640 medium for overnight growth. Cells were then treated with or without control or $\mathrm{aPL}^{+} \mathrm{IgG}$ at the indicated concentrations for 24 hours and then assayed for viability or proliferation. To assay viability, cells were incubated for 4 hours with $0.5 \mu \mathrm{g} / \mathrm{mL}$ of MTT assay (Sigma-Aldrich). The reduction of MTT was measured using a standard method. To assay proliferation, cells were incubated with $1 \mu \mathrm{mol} / \mathrm{L}$ bromodeoxyuridine (BrdU; Sigma-Aldrich), and BrdU incorporation was determined by immunoassay according to the manufacturer's instructions (Millipore-Calbiochem, Billerica, MA).

\section{Gene Expression Test}

Cells $\left(5 \times 10^{5}\right.$ per well) were placed in 6-well plates in RPMI 1640 medium containing $1 \%$ fetal bovine serum for overnight growth. Cells were then treated for the indicated times with 0.2 to $0.4 \mathrm{mg} / \mathrm{mL} \mathrm{aPL}^{+}$or control IgGs. RNA was extracted using TRIzol (Invitrogen/Life Technologies, Grand Island, NY) and reverse transcribed with the Superscript II system (Invitrogen/Life Technologies), according to the manufacturer's instructions. Primers were obtained from Real Time Primers (Elkins Park, PA), and real-time quantitative PCR was performed on Applied BioSystems 7900HT (Applied Biosystems/Life Technology, Grand Island, NY). Glyceraldehyde-3-phosphate dehydrogenase-normalized mRNA for specific gene expression was calculated by the $2^{-\Delta \Delta C_{T}}$ method using SDS software version 2.3 (Applied Biosystems/Life Technologies).

\section{In Vivo Assays}

\section{Xenografts}

Breast cancer xenografts were established by inoculation of human cancer cells $\left(5 \times 10^{5}\right.$ cells per site in $0.1 \mathrm{~mL}$ RPMI 1640 medium) into the thoracic or abdominal mammary glands of female nude mice at 7 to 10 weeks of age. For coinjection experiments, the inoculum was first incubated for 1 hour on ice in $0.1 \mathrm{~mL}$ RPMI 1640 medium containing $20 \mu \mathrm{g}$ total polyclonal human IgG from either healthy donors or patients; alternatively, $9.5 \mu \mathrm{g}$ affinity-purified $\mathrm{IgG}$ was used. For TF neutralization, the incubation was in the presence of $10 \mu \mathrm{g}$ antihuman TF antibody (American Diagnostica-Sekisui, Stamford, CT). For experiments using i.p. administration of human IgGs (rather than coinjection), one injection of $80 \mathrm{mg} / \mathrm{kg}$ body weight (bw) human IgG was administrated i.p. at day 14 after grafting. Mice were monitored every 7 days for the formation of visible tumors. Tumor incidence was calculated as the percentage of grafted glands bearing visible tumors. Tumor volumes were measured with a caliper for longest (L) and shortest (S) length and thickness (Th) by a blinded observer (Y.-Y.W., A.V.N., or E.Y.L.), and total volume was calculated as LxSxTh. Tumor volume in grafts of GFP-expressing tumor cells was determined weekly using a whole body Xenogen IVIS imaging system (Caliper Life Sciences, Hopkinton, MA). Background signal was measured using parallel mammary glands injected with $5 \times 10^{5}$ non-transduced cells.

\section{PyMT Model}

Female PyMT mice at 6 weeks of age were administered one i.p. injection of approximately $80 \mathrm{mg} / \mathrm{kg}$ bw human IgG. Tumors in all thoracic and abdominal mammary glands were analyzed for tumor stage by a blinded observer (Y.-Y.W., A.V.N., or E.Y.L.) using criteria established and described in detail in previous reports. ${ }^{25,26}$

\section{Determination of the Titer of Circulating Human aPLs in Mice}

Four mice per group were injected i.p. once with approximately $80 \mathrm{mg} / \mathrm{kg}$ bw aPL\#1 IgG or alternatively coinjected with $1 \times 10^{5}$ MDA-MB-436 cells and $20 \mu \mathrm{g}$ aPL\#1 IgG into each of two 
mammary glands. Approximately $100 \mu \mathrm{L}$ blood was collected from each mouse at the jugular vein every 7 days for 4 weeks (2 weeks for the coinjection group and 1 week for untreated controls). Control blood samples were collected from three untreated mice. The titers of aPS then were measured by the Immunodiagnostic Laboratory at MMC, as described above.

\section{Immunofluorescence}

For quantitation of tumor blood vessel density, vessels were labeled in vivo as described previously. ${ }^{27}$ Briefly, lysine-fixable, Texas Red-conjugated dextran (mol. wt.: 70,000) (Life Technologies), $6.2 \mathrm{mg} / \mathrm{mL}$ in PBS, was administrated i.v. (21 $\mu \mathrm{g} / \mathrm{gm}$ bw) 5 to 7 minutes before tissue harvest. We demonstrated that this method precisely marked endothelium-lined tumor vessels in mice. ${ }^{27}$ Tissues were fixed with $10 \%$ formalin, divided into sections, and counterstained with DAPI, and the entire tumor area was imaged. Vessel density was measured as the ratio of Texas Red-positive area/DAPIpositive area using WCIF ImageJ software version $1.37 \mathrm{a}$ (NIH, Bethesda, MD). For size matching of tumors, the longest diameters of tumors were determined from the tagged image file format images using Photoshop (Adobe, New York, NY). To obtain fluorescent images of tumor-associated macrophages, lysine-fixable fluorescein isothiocyanate-dextran (mol. wt.: 70,000) (Life Technologies), $6.2 \mathrm{mg} / \mathrm{mL}$ in PBS, was administrated i.v. $(21 \mu \mathrm{g} / \mathrm{g} \mathrm{bw}) 2$ hours before tissue harvest. We have previously demonstrated that this method specifically labels macrophages within the tumor. ${ }^{27}$

To assess $\alpha$-smooth muscle actin (SMA) - positive cells and their association with blood vessels, sections were simultaneously stained with a monoclonal anti- $\alpha$-SMA antibody (Sigma-Aldrich) and rabbit anti-von Willebrand factor (Dako, Carpinteria, CA), followed by Alexa Fluor-488conjugated goat anti-mouse $\operatorname{IgG} 2 \alpha$ and Texas Red-conjugated goat anti-rabbit antibodies (Molecular Probes/Life Technologies). Confocal images were prepared by the Analytic Imaging Core Facility at Einstein.

\section{IHC Data}

The antibodies used were rabbit anti-human annexin $\mathrm{A} 5,{ }^{28}$ rat anti-F4/80 (Caltag/Life Technologies), rat anti-Ly6G (clone: RB6-8C5) (BD Pharmingen, San Jose, CA), goat anti-TF (American Diagnostic-Sekisui, Stamford, CT), and mouse monoclonal anti-VEGF (Santa Cruz Biotechnology, Inc., Dallas, TX). Immunohistochemistry (IHC) was performed following standard procedures. For quantitation of leukocyte infiltration, the entire tumor area was imaged, and the ratio of diaminobenzidine-positive area/hematoxylin counterstain was determined using WCIF ImageJ software.

\section{In Vivo Matrigel Plug Assay}

Human breast cancer cells $\left(5 \times 10^{5}\right)$ were incubated on ice with $20 \mu \mathrm{g}$ control or $\mathrm{aPL}^{+} \mathrm{IgG}$, as in the coinjection procedure. BD Matrigel Matrix (Growth Factor Reduced; BD Biosciences, San Jose, CA) was added to a final concentration of approximately $70 \%$, and the mixture was injected into mammary gland. To label blood vessels in the plug, Texas Red-conjugated dextran was administered before harvest, as described above. Plugs were fixed in $10 \%$ formalin or zinc fixative (BD Biosciences) at $4{ }^{\circ} \mathrm{C}$ overnight and then paraffin embedded and divided into sections. Gross images of the plugs were obtained using a Zeiss STEMI (Zeiss, Thornwood, NY) at the Einstein Analytical Imaging Core Facility.

\section{Statistical Analysis}

The unpaired Student's $t$-test was used to assess significance for all data sets, with the exception of tumor incidence, PyMT tumor stage, and aPL incidence in breast cancer patients, which were analyzed using a Fisher's exact test.

\section{Results}

\section{0ccurrence of Elevated aPL Titer in Breast Cancer Patients}

In view of previous reports of aPL occurrence in cancer across multiple tumor types, ${ }^{10-12}$ we examined aPL status in newly diagnosed breast cancer patients at MMC (Table 1). Eight patients diagnosed with carcinoma in situ and 13 patients with invasive carcinoma were tested for seven classes of autoantibody frequently detected in APS patients. Of the 21 total patients, $6(29 \%)$ had elevated aPL according to international consensus laboratory criteria for APS. ${ }^{22}$ This value is consistent with previous reports of aPL prevalence in cancer. ${ }^{10-12}$ Notably, $6(46 \%)$ of 13 invasive cases were aPL positive, in comparison to 0 of 8 patients with noninvasive tumors $(P<0.05)$, consistent with a potential association of aPL with invasive malignancy.

\section{Promotion of Tumor Progression by Patient-Derived Antibodies}

To investigate the potential role of aPLs in tumor progression, we used IgGs from patients with autoimmune elevation

Table 1 aPL Titer in Patients with Breast Lesions

\begin{tabular}{llcc}
\hline $\mathrm{aPL}^{2}$ status & Carcinoma in situ $^{*}$ & Invasive carcinoma $^{\dagger}$ & Total \\
\hline $\mathrm{aPL}^{+}$ & 0 & 6 & 6 \\
$\mathrm{aPL}^{-}$ & 8 & 7 & 15 \\
Total & 8 & 13 & 21 \\
$\mathrm{aPL}^{+}$(\% total) & 0 & $46^{\ddagger}$ & 29 \\
\hline
\end{tabular}

aPL titer was determined by the Immunodiagnostic Laboratory at MMC. The test includes seven serological assays: anti-cardiolipin (IgM, IgG); anti$\beta$-2-glycoprotein I (IgM, IgG, IgA); and anti-phosphatidylserine (IgM, $\mathrm{IgG}$ ). Sera are classified as aPL positive if they are medium/high titer according to criteria established by international consensus. ${ }^{22}$ Samples with one or more positive outcomes were scored as aPL positive.

*Carcinoma in situ includes both ductal and lobular carcinoma in situ.

${ }^{\dagger}$ Invasive carcinoma includes invasive ductal or lobular carcinoma.

${ }^{\ddagger} P<0.05$ (Fisher's exact test). 
of circulating aPLs, including APS patients, because these samples are available in sufficient quantity for animal model studies. The serological findings for the $\mathrm{aPL}^{+}$patients and healthy donors (referred to as control IgG hereafter) used in this study are shown in Table 2. Orthotopic models of human breast cancer were generated by xenografting human breast cancer cell lines into mammary fat pads of nude mice. To enhance our ability to detect potential effects of aPLs on tumor progression, we selected two human breast cancer cell lines, MDA-MB-436 and MDA-MB-468, which are known to exhibit slow growth in xenograft models, potentially because of limited angiogenesis. ${ }^{30,31}$ As controls, we examined cell lines that display rapid growth in vivo, including MDA-MB-231 breast cancer cells and PC3 prostate cancer cells.

In pilot studies, we observed that tumors remained undetectable or $<2 \mathrm{~mm}$ in diameter for 4 weeks in $>70 \%$ of MDA-MB-436 or MDA-MB-468 xenografts. This observation is consistent with previous reports that $90 \%$ of fat pad xenografts of MDA-MB-436 cells remain undetectable for at least 30 days after grafting. ${ }^{30}$ In initial experiments, mice grafted with MDA-MB-436 cells at 7 weeks of age were administrated a single i.p. dose of either aPL\#1 or control \#1 polyclonal $\mathrm{IgG}(80 \mathrm{mg} / \mathrm{kg}$ bw $)$ at 2 weeks after grafting. In control IgG-injected mice, tumors remained undetectable in $>70 \%$ of grafts and mean tumor volume remained $<5 \mathrm{~mm}^{3}$ at 5 weeks after grafting (Figure 1, A and B). In contrast, mice treated with aPL\#1 IgG produced detectable tumors in $>80 \%$ of grafts at 5 weeks, with a mean volume of $>10 \mathrm{~mm}^{3}$ (Figure 1, A and B). Subsequently, the rate of tumor growth continued to increase in the $\mathrm{aPL}^{+}$IgG-treated, but not in the control IgG-treated, mice (Figure 1B). The volume of control tumors remained $<8 \mathrm{~mm}^{3}$, consistent with a dormant phenotype, ${ }^{32}$ whereas $\mathrm{aPL}^{+}$IgG-treated tumors were $>20$ $\mathrm{mm}^{3}$ within 4 weeks after IgG injection (Figure 1B). The effect of $\mathrm{aPL}^{+}$IgG was specific to cell lines with suboptimal growth, because equivalent tumor growth was observed in control and $\mathrm{aPL}^{+}$IgG-injected mice grafted with more aggressive MDA-MB-231 breast cancer cells (data not shown) or PC3 prostate cancer cells (Figure 1C). To determine whether aPL levels achieved in the mouse model were representative of patient levels, we assessed human aPL titer

Table 2 aPL Titer (IgG Isotype) in Serum of $\mathrm{aPL}^{+}$Patients and Healthy Donors

\begin{tabular}{llcc}
\hline Normal cutoff & $\mathrm{aCL}<23$ & $\mathrm{aPS}<16$ & $\beta 2 \mathrm{GPI}<20$ \\
\hline aPL\#1 & 30.6 & 78.5 & $>154$ \\
aPL\#2 & 50 & 50 & 57 \\
aPL\#3 & 12.9 & 100 & 152 \\
Control 1 & 0.34 & 1.18 & $<5.0$ \\
Control 2 & 2.71 & 1.98 & 0.84 \\
Control 3 & 1.75 & 3.4 & 0.21 \\
Control 4 & 1.73 & 0.63 & 0.14 \\
Control 5 & 2.19 & 0.92 & 0.28 \\
\hline
\end{tabular}

Data are given as $\mathrm{U} / \mathrm{mL}$. aPL titer is determined by the Immunodiagnostic Laboratory at MMC. One unit is equivalent to $1 \mu \mathrm{g} / \mathrm{mL}$ of affinity-purified IgG. ${ }^{29}$ in the circulation of injected mice. The circulating level of aPL\#1 IgG at 1 week after injection was near the abnormal cutoff value in patients, and declined with a half-life of 9.3 days (Supplemental Figure S1), consistent with previous halflife estimates in mice for human $\operatorname{IgG} 1$ and $\operatorname{IgG} 2,{ }^{33,34}$ the major isotypes in patient aPL. ${ }^{35,36}$

To extend these findings to a spontaneous breast cancer model, we used PyMT mice, in which mammary tumors are induced by the transgenic expression of the polyoma middle $\mathrm{T}$ oncogene specifically in mammary epithelial cells. Mammary tumors in this model progress through stages comparable to the human disease, including an onset of angiogenic switch and pulmonary metastasis. ${ }^{25,26}$ The reactivity of human aPL with murine antigens is indicated by the use of these antibodies in several studies to induce pathological effects in mice, similar to symptoms observed in patients with APS, including pregnancy loss, fetal injury, and arterial thrombosis. ${ }^{37-39}$ In $\beta-2$ glycoprotein I, the phospholipid-binding protein that serves as the major pathogenic target of human aPL, ${ }^{40,41}$ the N-terminal domain to which aPL binds is perfectly conserved between mouse and human. ${ }^{42}$ This domain has been shown to mediate direct binding of human aPL to murine $\beta-2$ glycoprotein I. ${ }^{41}$ In pilot studies, we observed that PyMT mice with $\mathrm{C} 57 \mathrm{~B} 1 / 6$ background (used in this study) progressed to malignant stages at 8 to 9 weeks of age, representing an approximately 2 -week delay relative to the earlier studies with this model in mixed genetic background. ${ }^{25}$ Consequently, we administered one i.p. injection of either control or $\mathrm{aPL}^{+}$IgG to the PyMT mice in this background at 6 weeks of age, when most tumors were at premalignant stages, and analyzed tumor stages at 9 weeks of age. In contrast to control IgG, a single treatment with $\mathrm{aPL}^{+} \mathrm{IgG}$ resulted in a sevenfold increase in the frequency of histological progression from early to late carcinoma within 3 weeks (Figure 1, D and E).

Tumor cells often display high levels of cell surface anionic phospholipids, ${ }^{4,43,44}$ potential targets of aPL, suggesting that local interaction between aPL and tumor cells may affect tumor progression. Because cell surface anionic phospholipids are expected to interact with the circulating protein annexin $\mathrm{A} 5,{ }^{45}$ we performed immunostaining to assess annexin A5 in xenografted tumors. We observed a marked localization of annexin A5 to tumor, compared with adjacent normal tissue (Figure $1 \mathrm{~F}$ and Supplemental Figure S2A). High levels of annexin A5 were also observed in PyMT mammary tumors (Supplemental Figure S2A). These data are consistent with the presence of a cell surface target for aPL in tumors, although we cannot exclude that local expression of intracellular annexin A5 may also contribute to the observed staining.

To further distinguish local and systemic effects of aPL administration, we developed a coinjection protocol, in which breast cancer cells were preincubated for 1 hour on ice with $20 \mu \mathrm{g}$ of $\mathrm{aPL}^{+}$or control IgG. Cells with $\mathrm{aPL}^{+}$IgG were then grafted ipsilaterally and cells with control $\operatorname{IgG}$ 
A

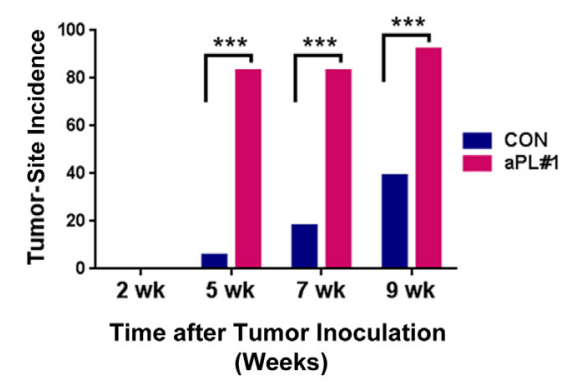

D

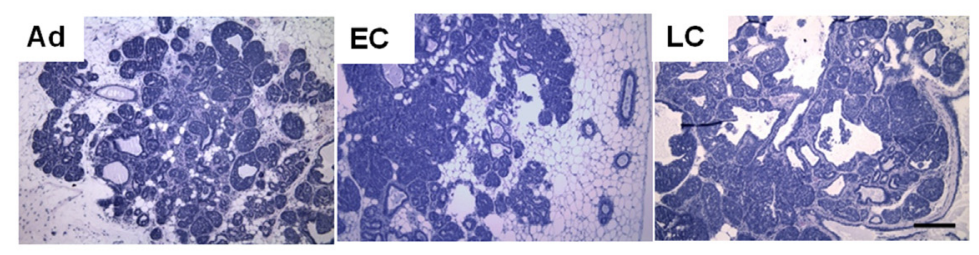

F
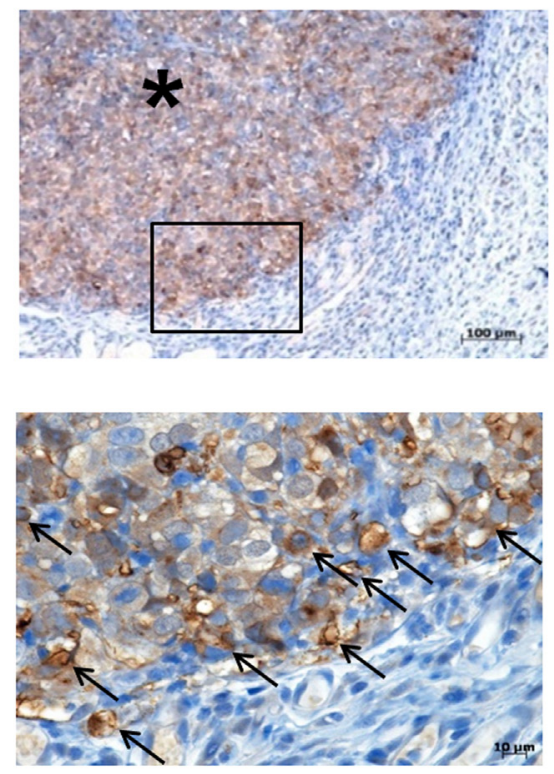

B
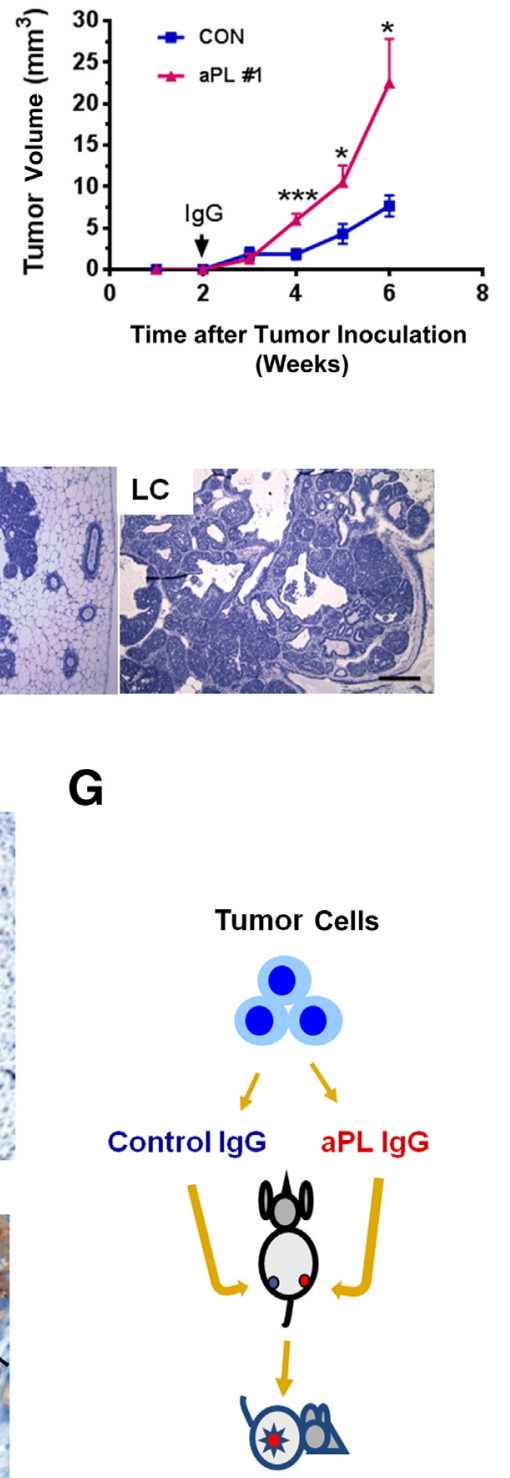

E



H

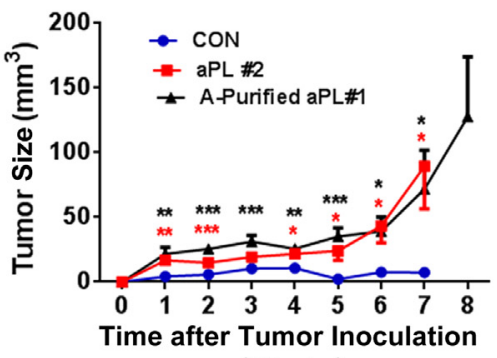

(Weeks)

C

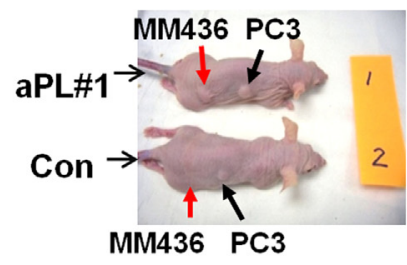

1



(Weeks)

Figure 1 Effect of antiphospholipid antibodies (aPL)-positive IgG on tumor progression. A-C: Nude mice were xenografted with $5 \times 10^{5}$ human tumor cells per mammary gland. At 2 weeks after grafting, mice were injected i.p. once with $80 \mathrm{mg} / \mathrm{kg}$ body weight (bw) control (CON) or aPL\#1 patient IgG (aPL\#1). Mice were assessed for percentage of MDA-MB-436 grafts with visible tumors $(n=18$, control; $n=12$, aPL\#1; A) and tumor volume ( $n=10$, each group; B). The results represent pooled data from three experiments. C: Mice with mammary glands grafted with the indicated cell lines (MDA-MB-436: MM436) and treated i.p. (one injection 2 weeks after grafting) with the indicated IgGs were photographed at 12 weeks after grafting. PC3 tumors occur in both mice, whereas MDA-MB-436 tumors occur only on APS IgG injection. D and E: Progression of spontaneous tumors in PyMT mice. Female PyMT mice ( 6 weeks old) were injected i.p. with $80 \mathrm{mg} /$ $\mathrm{kg}$ bw normal (CON) or aPL\#1 IgG. Tumors were collected at 9 weeks of age and scored as adenoma (Ad), early carcinoma (EC), or late carcinoma (LC) (D). Error bars: $200 \mu \mathrm{m}$. A significant difference in the frequency of LC was observed (E) ( $n=26$ for each group). F: IHC for annexin A5 in MDA-MB-436 xenografts. The tumor is indicated by an asterisk. The boxed area in the top panel is shown at higher magnification on the bottom panel. Arrows indicate cell surface staining. G: Illustration of coinjection procedure. $\mathbf{H}$ and I: Tumor volume was determined after coinjection of MDA-MB-436 (H) or MDA-MB-468 (I) cells with normal IgG (CON), aPL ${ }^{+}$IgG, or affinity-purified (A-purified) aPL IgG. Sample sizes: H: $n=16,11$, and 14 for CON, aPL\#2, and A-purified aPL\#1, respectively. I: $n=15$ and $n=18$ for CON and aPL\#2, respectively. ${ }^{*} P<0.05,{ }^{*} P<0.01$, and ${ }^{* * *} P<0.001$ versus controls $(\mathbf{A}, \mathbf{B}, \mathbf{E}$, and $\mathbf{H})$.

contralaterally in the same mice (Figure 1G). Tumor volumes were determined at each injected site at weekly intervals. By using three different $\mathrm{aPL}^{+} \mathrm{IgGs}$, matched with three different control IgGs, we consistently observed a significant increase in the volume of MDA-MB-436 tumors within 1 week after grafting at $\mathrm{aPL}^{+}$IgG-injected sites compared with control sites, at which growth was delayed and variable (Figure $1 \mathrm{H}$ and Supplemental Figure S2, B and C). After this initial 

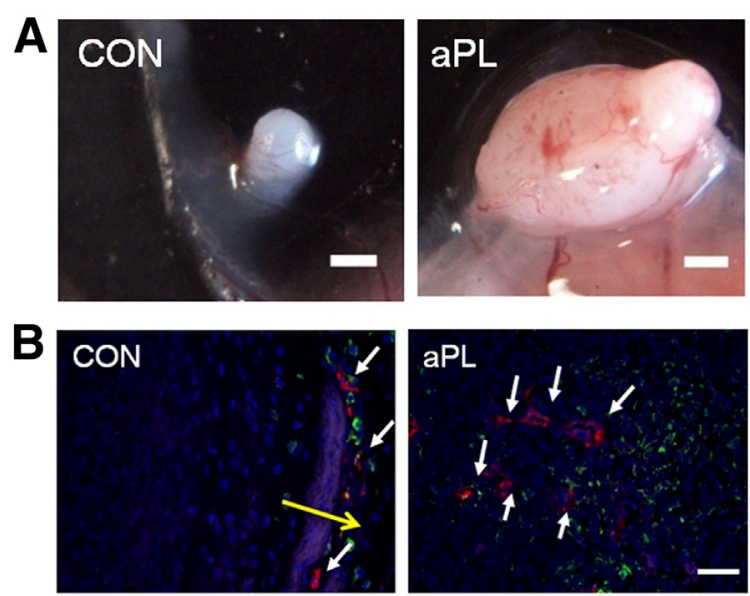

C

Small Tumors $(<1.5 \mathrm{~mm})$
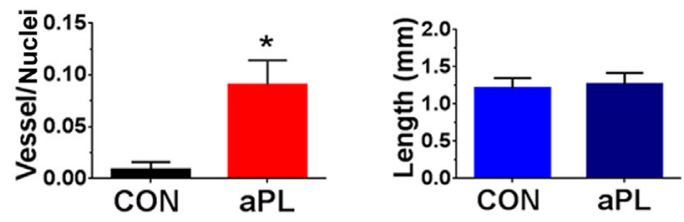

D
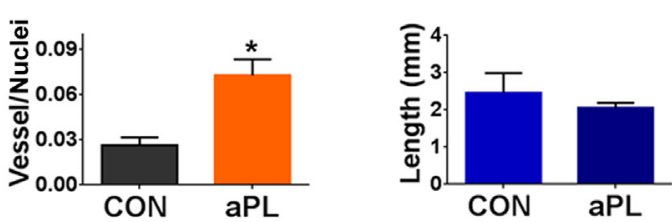

E

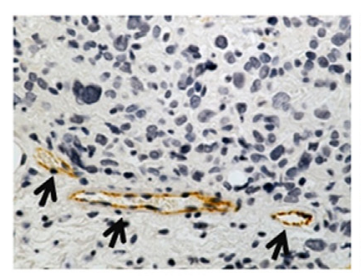
CON



$\mathbf{F}$

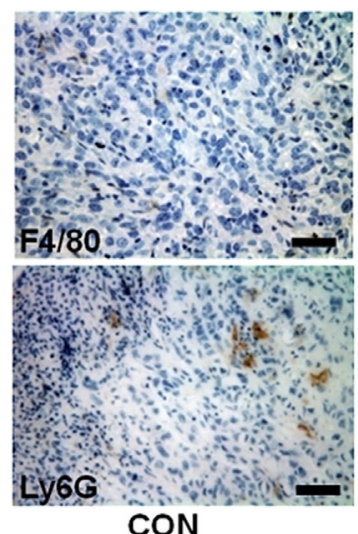
CON

G

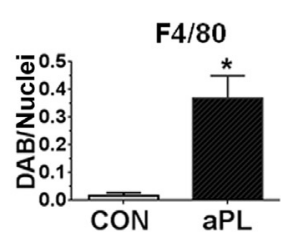

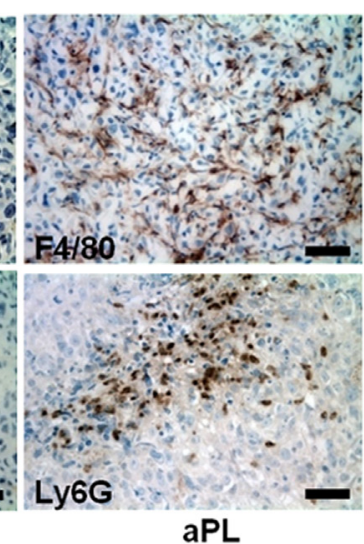

Ly6G



period of $\mathrm{aPL}^{+}$IgG-stimulated growth, tumor size was maintained with little change for several weeks (Figure $1 \mathrm{H}$ and Supplemental Figure S2, B and C) until 5 to 6 weeks after grafting, at which time $\mathrm{aPL}^{+}$IgG-treated sites produced rapidly expanding tumors, whereas control IgG-treated sites remained comparatively quiescent (Figure 1H). Although the magnitude of tumor growth showed some experimental variation, the distinct kinetics stimulated by $\mathrm{aPL}^{+} \mathrm{IgG}$, with respect to both initial growth and later tumor expansion, were a consistent finding and were verified with a second human breast cancer cell line, MDA-MB-468 (Figure 1I). To obtain further evidence for the tumor-accelerating effect of aPL, aPL was affinity purified from aPL\#1 IgG using liposomes bearing a cardiolipin/phosphatidylserine mixture. Xenografts coinjected with affinity-purified aPL displayed stimulation of tumor growth comparable to that observed with whole aPL\#2 IgG (Figure $1 \mathrm{H}$ ). Taken together, these observations indicate that aPL can act locally at tumor sites to promote early tumor growth and long-term tumor progression.

\section{Promotion of Tumor Angiogenesis by $\mathrm{aPL}^{+} \mathrm{IgG}$}

No effect of $\mathrm{aPL}^{+} \mathrm{IgG}$ on the proliferation or survival of cultured MDA-MB-436 cells was observed (Supplemental Figure S2, D and E), suggesting that it is unlikely that $\mathrm{aPL}^{+} \mathrm{IgG}$ promotes tumor progression through a direct effect on tumor cell growth. We next considered whether the tumor-accelerating effect of aPL is associated with an onset of tumor angiogenesis, because previous studies have indicated that accelerated growth of MDA-MB-436 xenografts is angiogenesis dependent. ${ }^{30,46} \mathrm{We}$ observed that tumors from $\mathrm{aPL}^{+}$IgG-treated grafts were more vascularized than control tumors at 6 weeks after grafting (Figure 2A). Control grafts displayed blood vessels in the stromal region, but intratumoral vessels were at low density in comparison to

\footnotetext{
Figure 2 Effects of antiphospholipid antibodies (aPL)-positive IgG on tumor angiogenesis and leukocytic infiltration. A: Representative tumors imaged at 6 weeks after coinjection of MDA-MB-436 cells with normal (CON) or $\mathrm{aPL}^{+} \mathrm{IgG}$. B: Mice were injected i.p. with normal (CON) aPL\#1 IgG 2 weeks after grafting MDA-MB-436 cells, and tumors were collected at 6 weeks after grafting for assessment of blood vessels and macrophages labeled with red and green fluorescent dextran, respectively. White arrows indicate labeled blood vessels; yellow arrow, tumor stroma. No vessels were observed within the imaged control tumor. $\mathbf{C}$ and $\mathbf{D}$ : The ratio of vessel density (Texas Red dextran intensity)/nuclear signal (DAPI) was compared between size-matched tumors in normal $(\mathrm{CON})$ and $\mathrm{aPL}^{+} \mathrm{IgG}$-treated MDAMB-436 grafts ( $n=3$ to 5). Tumor sizes, based on longest length, are displayed in the right half of each panel. E: MDA-MB-436 xenografts coinjected with control (CON) or $\mathrm{aPL}^{+} \mathrm{IgG}$ were stained to detect smooth muscle actin. Arrows point to positively stained blood vessels in tumors. $\mathbf{F}$ and $\mathbf{G}: \mathrm{aPL}^{+}$IgG-induced leukocytic infiltration in xenografts. F: MDA-MB436 xenografts from mice injected i.p. with control (CON) or aPL ${ }^{+} \mathrm{IgG}(\mathrm{aPL})$ were stained to detect macrophages (F4/80) or neutrophils (Ly6G). G: Leukocytic infiltration in $\mathbf{F}$ was quantitated as the ratio of diaminobenzidine signal/nuclear counterstain. For F4/80, $n=3$ (CON) or $n=4(\mathrm{aPL})$; for Ly6G, $n=4(\mathrm{CON})$ or $n=6(\mathrm{aPL})$. ${ }^{*} P<0.05$ versus controls (C, D, and G). Scale bars: $1 \mathrm{~mm}(\mathbf{A}) ; 50 \mu \mathrm{m}$ (B and F); $30 \mu \mathrm{m}(\mathbf{E})$.
} 
$\mathrm{aPL}^{+}$IgG-treated tumors (Figure 2B), suggesting increased angiogenesis in $\mathrm{aPL}^{+}$IgG-treated tumors. However, it could not be determined from this observation whether angiogenesis was promoted by $\mathrm{aPL}^{+} \mathrm{IgG}$ or was simply a consequence of the acceleration of growth. We, therefore, quantitated vessel density in size-matched tumors from grafts exposed to $\mathrm{aPL}^{+}$or control $\mathrm{IgG}$, using a fluorescent labeling approach that we have validated for this purpose in previous studies. ${ }^{27}$ The analysis revealed a pronounced effect of $\mathrm{aPL}^{+} \mathrm{IgG}$ on tumor angiogenesis independent of tumor size (Figure 2, C and D). Notably, the enhancement of angiogenesis by $\mathrm{aPL}^{+} \mathrm{IgG}$ was greater ( $>10$-fold) for size-matched tumors $<1.5 \mathrm{~mm}$ in diameter than for larger tumors, which displayed a less than threefold increase of vessel density (Figure 2, C versus D). This observation suggests that a proangiogenic effect occurs at an early stage of tumor acceleration by aPL. The ability of aPL to exert early effects on tumor progression is further indicated by the appearance of invasive histological features in small tumors in $\mathrm{aPL}^{+}$IgG-treated grafts, compared with size-matched control tumors in which capsules remain well defined and undisturbed (Supplemental Figure S3).
To further probe the effects of $\mathrm{aPL}^{+} \mathrm{IgG}$ on angiogenesis, we examined the coverage of tumor vessels with mural cells expressing SMA. Vessels in $\mathrm{aPL}^{+}$IgG-treated tumors displayed well-developed mural layers, with SMA organization indicative of parallel bundles of filaments forming a continuous perivascular sheath (Figure 2E), which has been observed as a characteristic feature of pericytes in normal vessels. ${ }^{47}$ In control IgG-treated tumors, the vessels available for comparison were near the transition between tumor and stroma. These peripheral vessels were mostly surrounded by mural layers that were thinner and less developed than those of $\mathrm{aPL}^{+} \mathrm{IgG}$-treated tumors (Figure 2E).

Because we and others have observed an involvement of tumor-associated macrophages in angiogenic switch, ${ }^{26,48}$ we examined the effect of $\mathrm{aPL}^{+}$IgG on leukocytic infiltration. We observed more macrophages as judged by dextran labeling in $\mathrm{aPL}^{+}$IgG-treated tumors (Figure 2B). A quantitative analysis revealed a $>10$-fold increase in the density of $\mathrm{F} 4 / 80^{+}$macrophages in $\mathrm{aPL}^{+}$IgG- compared with control IgG-treated tumors (Figure 2, F and G). Dense focal accumulations of $\mathrm{Ly} 6 \mathrm{G}^{+}$neutrophils were also frequently observed in $\mathrm{aPL}^{+}$IgG-treated tumors, although this effect
A

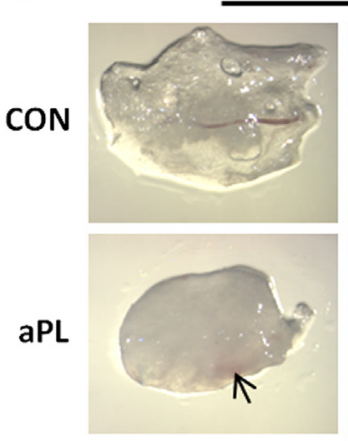

B

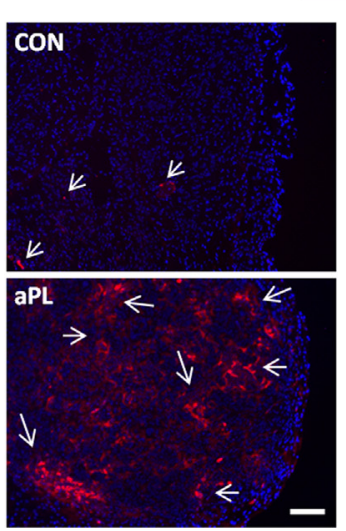

$3 D$

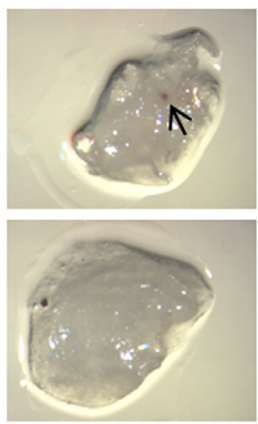

C
6D
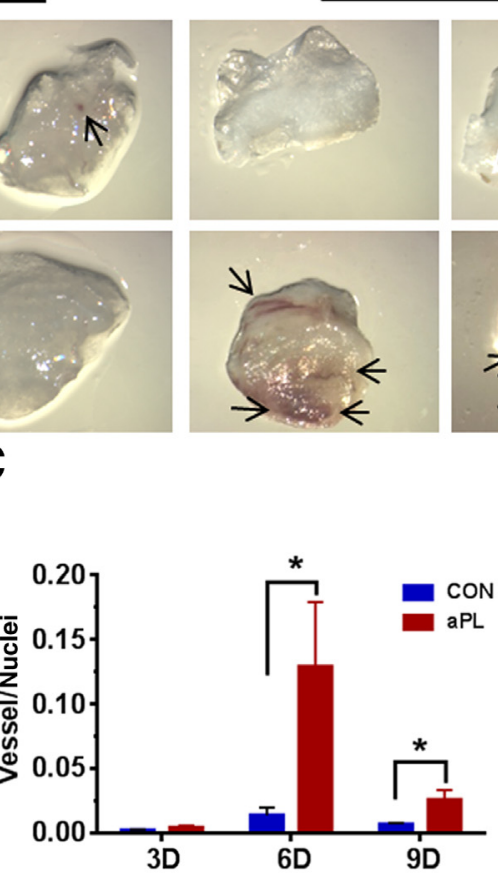

9D

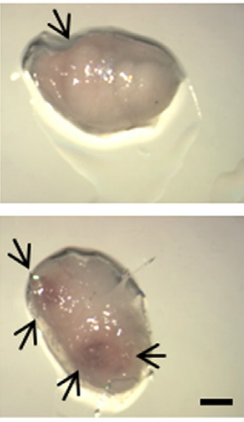

D

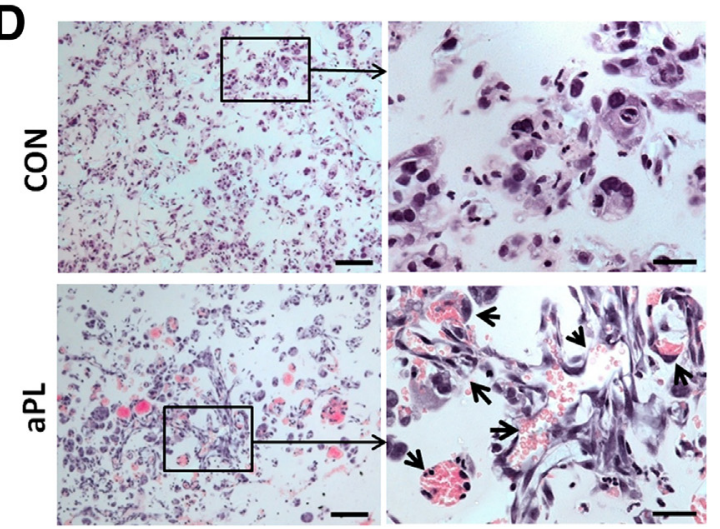

Figure 3 Kinetics of antiphospholipid antibodies (aPL)-induced tumor angiogenesis. A: Representative gross images of Matrigel plugs harvested at 3, 6 , and 9 days after grafting (3D, 6D, and 9D, respectively). Plugs were generated in mammary glands of nude mice by inoculating Matrigel-containing MDA-MB436 cells and $20 \mu \mathrm{g}$ of either control (CON) or $\mathrm{aPL}^{+}(\mathrm{aPL}) \mathrm{IgG}$. Arrows indicate vessel formation visible at the surface of the plug. B and C: Vessel density in Matrigel plugs. B: Representative images of sections of Matrigel plugs containing either control or aPL IgGs, harvested at day 6 after grafting. Arrows indicate blood vessels labeled with Texas Red dextran. C: Vessel density is quantitated as the ratio of Texas Red dextran intensity/DAPI nuclear counterstain (vessel/nuclei) in tumors harvested at 3D, 6D, and 9D. $n=3$ to 4 (3D), 6 (6D), or 4 (9D). D: Representative hematoxylin and eosin -stained sections of tumors in Matrigel plugs harvested at day 6 after grafting. The boxed areas in the left panels are shown at higher magnification on the right panels. Arrows indicate tumor vessels. ${ }^{*} P<0.05$ (C). Scale bars: $1 \mathrm{~mm}(\mathbf{A}) ; 100 \mu \mathrm{m}$ (B and D, left panels); $30 \mu \mathrm{m}$ (D, right panels). 
did not achieve statistical significance (Figure 2, F and G). IgGs treated with Detoxi-Gel to remove endotoxin gave similar results (data not shown), indicating that the effect of aPL is not due to the endotoxin contamination in $\mathrm{aPL}^{+} \mathrm{IgG}$. Taken together, these observations suggest that aPL has the potential to promote tumor progression by stimulating angiogenesis and inflammatory reactions at the tumor site.

\section{Kinetics of Tumor Angiogenesis in Response to $\mathrm{aPL}^{+}$ IgG}

To further examine the time course of $\mathrm{aPL}^{+} \mathrm{IgG}$-stimulated angiogenesis, it was necessary to examine time points within 1 week of aPL exposure. Because the xenograft provides limited material at these early time points, we chose to examine a Matrigel xenograft model. Matrigel plugs, in which MDA-MB-436 cells were combined with either control or $\mathrm{aPL}^{+} \mathrm{IgG}$, were implanted and harvested at 3 , 6, and 9 days after grafting. Gross examination of the plugs (Figure 3A) revealed only minimal vessel development at 3 days. At 6 days, vessel development had clearly progressed in $\mathrm{aPL}^{+} \mathrm{IgG}$, but not in control IgG plugs. By day 9, vessel development was evident in control plugs, but remained more pronounced in $\mathrm{aPL}^{+} \mathrm{IgG}$ plugs. Quantitative microscopic analysis of vessels labeled with dextran (administered before harvest ${ }^{27}$ ) confirmed these findings: vessel density was significantly elevated in $\mathrm{aPL}^{+} \mathrm{IgG}-$ treated compared with control IgG-treated plugs at both 6 and 9 days after implant (Figure 3, B and C). These findings were confirmed by histological analysis, which demonstrated a high density of blood vessels in $\mathrm{aPL}^{+}$IgG but not IgG-treated Matrigel plugs (Figure 3D).

\section{Proangiogenic Gene Expression in $\mathrm{aPL}^{+}$IgG-Treated Tumor Cells}

We next sought to identify aPL-induced factors that may regulate angiogenesis and tumor progression. Because our studies indicate that aPL interacts locally with tumor (Figure 1, $\mathrm{F}, \mathrm{H}$, and I), and aPL is known to modulate gene expression in target cells, ${ }^{49}$ we considered that aPL might interact with cells in the tumor to promote angiogenesis. Previous studies have demonstrated that aPL can induce expression in macrophages of both VEGF-A and TF, central regulators of angiogenesis. ${ }^{21}$

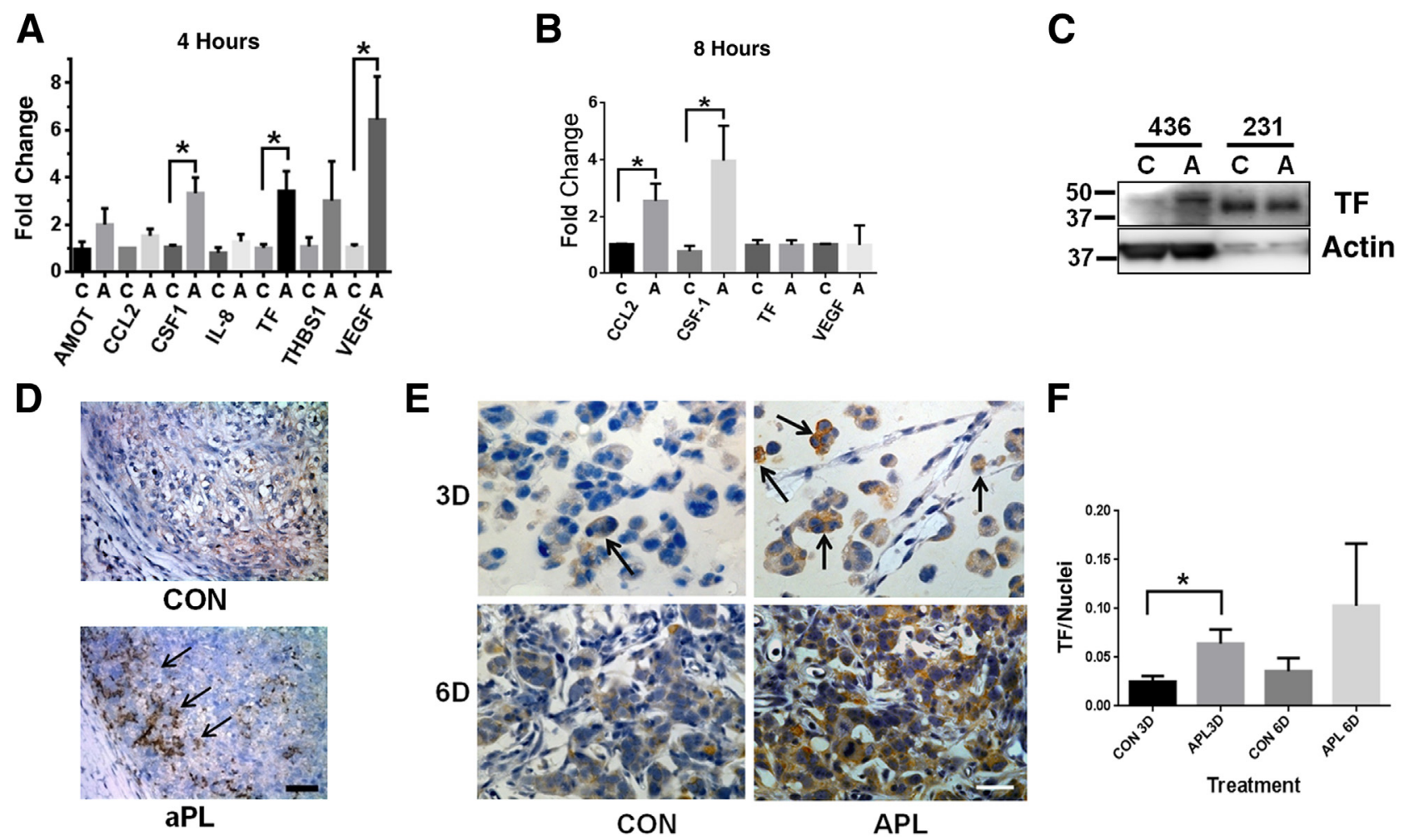

Figure 4 Effects of antiphospholipid antibodies (aPL)-positive IgG on gene and protein expression. A and B: Real-time quantitative PCR analysis of gene expression in cultured MDA-MB-436 cells treated with control (C) or $\mathrm{PPL}^{+}(\mathrm{A})$ IgG for 4 or 8 hours. For $\mathrm{A}, n$ is 5, 4, 4, 5, 9, 5, or 6 for angiomotin (AMOT), CCL2, CSF1, IL-8, tissue factor (TF), thrombospondin 1 (THBS1), or VEGF, respectively. For B, $n$ is 4, 7, 8, or 4 for CCL2, CSF1, TF, or VEGF, respectively. C: Western blot analysis of cell lysates for MDA-MB-436 (30 $\mu$ /lane 436) or MDA-MB-231(3 $\mu \mathrm{g} /$ lane 231) cells treated with control (C) or aPL\#1 (A) IgG for 24 hours. Molecular weight markers are indicated on the left. D: IHC for TF in MDA-MB-436 tumors in mice injected i.p. with normal (CON) or aPL $(\mathrm{aPL}) \mathrm{IgG} 2$ weeks after grafting. Tumors were collected 7 weeks after IgG injection. Arrows indicate positive staining. E: IHC for TF in Matrigel plugs containing MDA-MB-436 cells and either control (CON) or aPL ${ }^{+}(\mathrm{APL})$ IgG. Plugs were harvested on day 3 or 6 after grafting (3D or 6D, respectively). Arrows in day 3 images indicate positively stained cells. F: TF protein expression in Matrigel plugs was quantitated as the ratio of TF stain/nuclear counterstain (hematoxylin) ( $n=4)$. ${ }^{*} P<0.05$ (A, B, and F). Scale bars: $50 \mu \mathrm{m}$ (D); $30 \mu \mathrm{m}$ (E). 
However, the ability of aPL to act directly on tumor cells to promote a proangiogenic phenotype has not been examined. $\mathrm{We}$, therefore, investigated the effect of $\mathrm{aPL}^{+} \mathrm{IgG}$ treatment on the expression of a panel of proangiogenic and proinflammatory genes in human breast cancer cells. Treatment of MDA-MB- 436 cells with $\mathrm{aPL}^{+} \mathrm{IgG}$ for 4 hours, in comparison to control $\mathrm{IgG}$, resulted in a significant elevation of the gene expression of TF and VEGF, as well as the macrophage growth factor colony-stimulating factor-1 (CSF1) (Figure 4A), which we and others have linked to tumor progression and angiogenesis. ${ }^{25,27,50}$ In contrast, the expression of other angiogenesis-related factors in human breast cancer cells, including thrombospondin 1, angiomotin, and IL-8 (alias
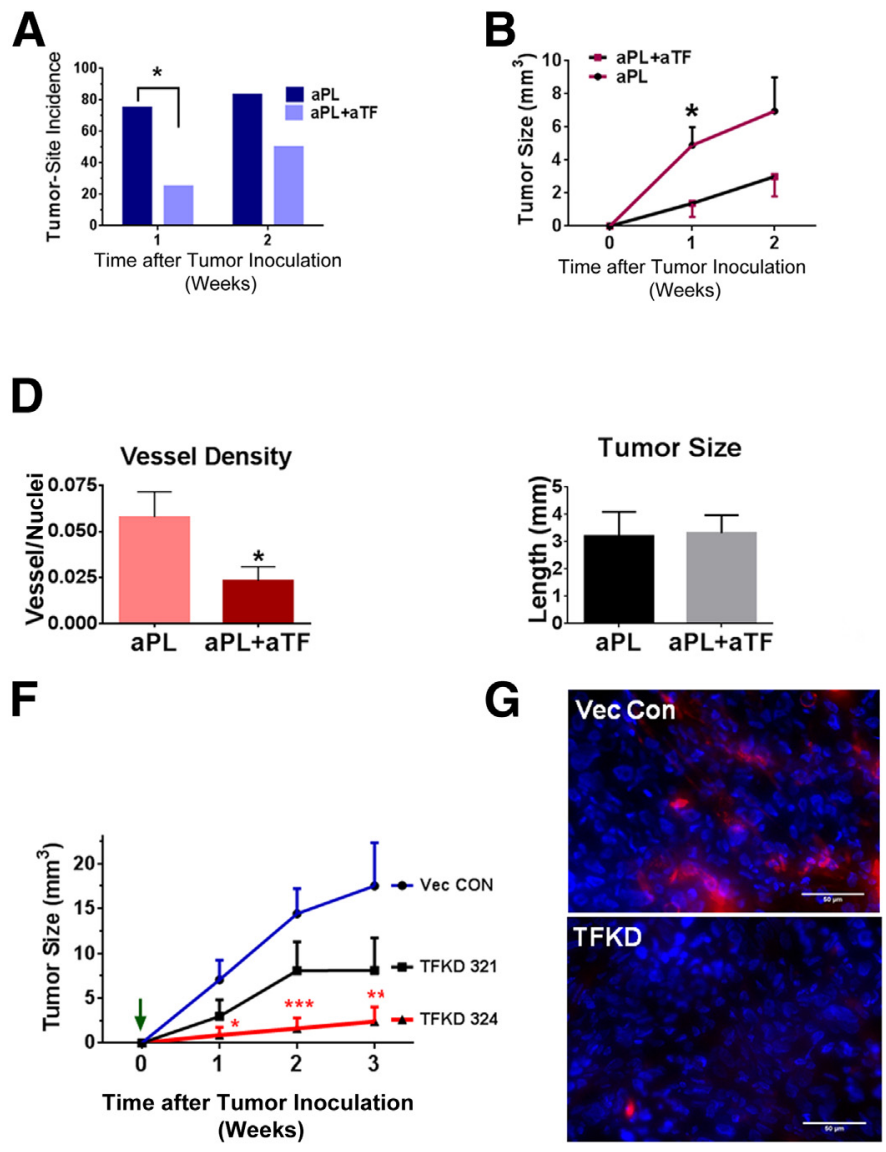

CXCL8), was not significantly affected by $\mathrm{aPL}^{+} \mathrm{IgG}$ (Figure 4A). At 8 hours of treatment, the expression of chemokine ligand 2 (CCL2), which has been implicated in tumor angiogenesis and monocyte recruitment, ${ }^{51-53}$ became significantly elevated, whereas expression of TF and VEGF returned to baseline levels (Figure 4B). The expression of CSF1 remained elevated at 8 hours (Figure $4 \mathrm{~B}$ ).

\section{Regulation of TF Protein Expression by $\mathrm{aPL}^{+} \mathrm{IgG}$}

We chose to evaluate $\mathrm{TF}$ as a potential mediator of $\mathrm{aPL}^{+}$ IgG effects on tumor angiogenesis and growth, because TF can potentially support angiogenesis via several pathways,
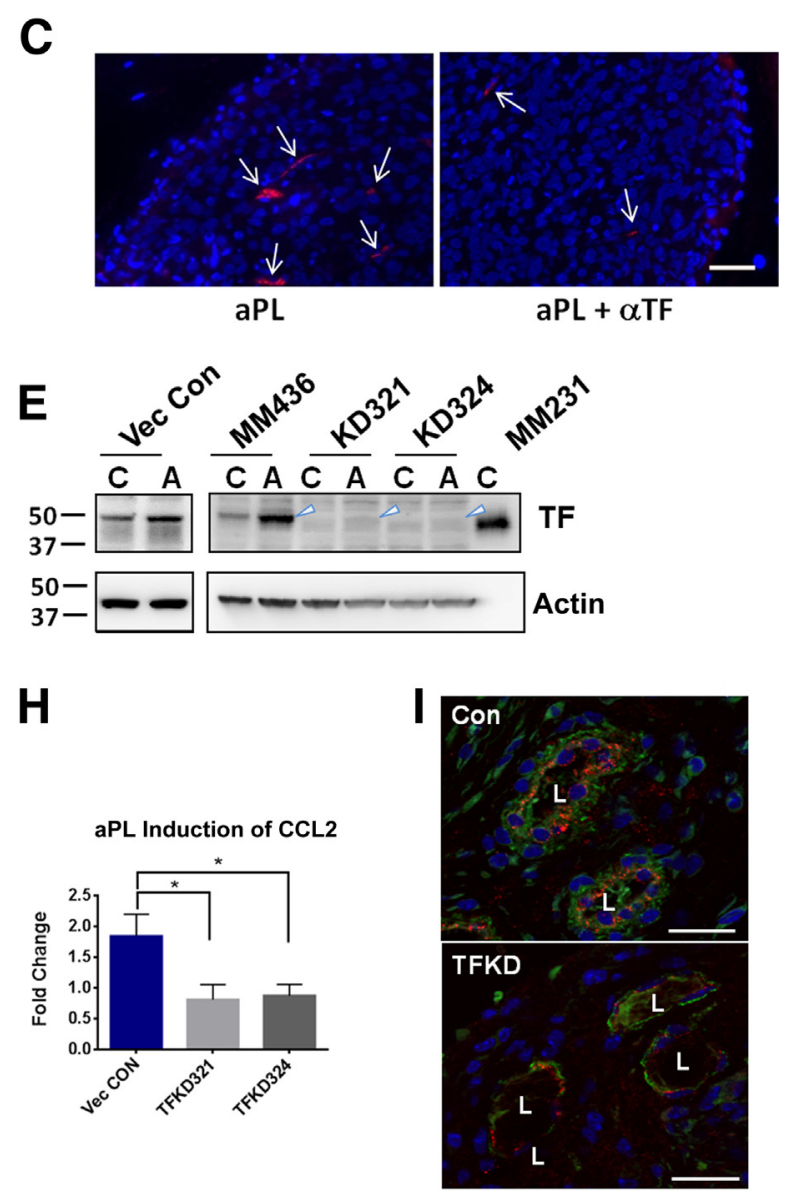

Figure 5 Role of tissue factor (TF) in antiphospholipid antibodies (aPL)-positive IgG-dependent tumor angiogenesis. A and B: Tumor incidence (A) and tumor growth (B) were assessed in mice coinjected with MDA-MB-436 cells and $\mathrm{aPL}^{+} \mathrm{IgG} \pm$ neutralizing anti-TF antibody ( $\left.\alpha \mathrm{TF}\right)(n=12$ for each condition). The result was pooled from two separate experiments. C: Representative images of tumors collected 3 weeks after grafting of MDA-MB-436 cells with aPL IgG \pm anti-TFneutralizing antibody $(\alpha \mathrm{TF})$ and labeled with Texas Red-conjugated dextran to detect blood vessels (arrows). D: The ratio of vessel density (Texas Red dextran intensity)/nuclear signal (DAPI) was compared between size-matched tumor generated by coinjection with the aPL ${ }^{+} \mathrm{IgG}$ (APL) \pm anti-TF-neutralizing antibody $(\alpha \mathrm{TF})$ at 3 weeks after grafting $(n=7)$. E-I: Effects of TF knockdown in tumor cells on xenografted tumors. E: Western blot analysis of cell lysates $(25 \mu \mathrm{g}$ protein) of parental (MM436), vector control (Vec Con), or TF-knockdown (KD321, KD324) MDA-MB-436 cells treated with control (C) or aPL\#1 (A) IgG for 24 hours. Untreated MDA-MB-231 cells are shown for comparison (MM231; $5 \mu \mathrm{g}$ protein). Molecular weight standards are indicated on the left. Arrowheads pointed to aPL-induced TF in parental or TF-knockdown tumors. F: Tumor size was monitored after coinjection of aPL ${ }^{+}$IgG with MDA-MB-436 cells carrying control (Vec CON) or the indicated TFknockdown lentiviruses. G: Representative images of tumors collected 4 weeks after coinjection of aPL ${ }^{+} \mathrm{IgG}$ and MDA-MB-436 cells bearing either control (Vec Con) or TFKD324 (TFKD) lentiviral constructs. Blood vessels (arrows) were in vivo labeled with Texas Red-conjugated dextran. H: CCL2 RNA level in MDA-MB-436 cells bearing either control (Vec CON) or the TF-knockdown (TFKD324; TFKD) lentiviral constructs. Cells were treated with aPL ${ }^{+}$IgG for 8 hours. I: Vessel-associated SMA. Representative confocal images of immunofluorescence staining of SMA (green) to detect mural cells and von Willebrand factor (red) to detect endothelial cells. Images are from the peripheral region of tumors derived by coinjection of aPL\#1 IgG with either parental (Con) or TFKD324 lentiviral construct (TFKD) bearing MDA-MB-436 cells ( 4 weeks after grafting). Vessel-associated SMA stain is prominent in control tumors but not in TF-knockdown tumors. ${ }^{*} P<0.05,{ }^{* *} P<0.01$, and $* * * P<0.001 . n=5(\mathbf{H})$. Scale bar $=50 \mu \mathrm{m}(\mathbf{C}, \mathbf{G}$, and $\mathbf{I})$. L, vessel lumens. 
including procoagulant action and direct induction of proangiogenic gene expression. Protein expression analysis of MDA-MB-436 cells treated with $\mathrm{aPL}^{+}$IgG for 24 hours demonstrated up-regulation of an approximately $49-\mathrm{kDa}$ species (Figure 4C), consistent with full-length TF protein. ${ }^{54}$ In comparison, MDA-MB-231 cells, which form aggressive, $\mathrm{aPL}^{+}$IgG-independent tumors when grafted to mammary fat pads (data not shown), displayed a high baseline level of TF expression (consistent with a previous report ${ }^{55}$ ) that was little affected by $\mathrm{aPL}^{+} \mathrm{IgG}$ treatment (Figure 4C). The difference in TF mobility between the two cell lines is similar to previously observed variation attributable to variable glycosylation. ${ }^{56}$

We next examined TF protein expression in tumors in vivo. Seven weeks after IgG injection of MDA-MB-436 xenograft-bearing mice, we observed foci of intense $\mathrm{TF}$ expression in tumors from $\mathrm{aPL}^{+} \mathrm{IgG}$-treated mice compared with weaker diffuse staining in control IgG-treated mice (Figure 4D). To examine tumor TF expression at early time points, we used the Matrigel plug model. At 3 days after grafting, plugs containing $\mathrm{aPL}^{+}$IgG-treated tumor cells displayed a marked increase in TF-expressing cells compared with control IgG-treated plugs (Figure 4E). Most of the TF-expressing cells had the morphological appearance of tumor cells (Figure 4E). Quantitative analysis indicated $\mathrm{aPL}^{+}$IgG stimulation of plug TF expression at 3 and 6 days after grafting, although statistical significance was not achieved at 6 days because of variation (Figure 4F).

\section{Role of Tumor Cell-Derived TF in $\mathrm{aPL}^{+}$IgG-Promoted Tumor Progression}

We next sought to investigate the potential role of $\mathrm{aPL}^{+}$ IgG-induced $\mathrm{TF}$ in tumor progression. When MDA-MB436 cells were coinjected with both $\mathrm{aPL}^{+} \mathrm{IgG}$ and an anti-TF neutralizing antibody, tumor incidence and tumor size at 1 week after grafting were reduced by $67 \%$ to $71 \%$ compared with MDA-MB-436 coinjected with $\mathrm{aPL}^{+}$IgG alone (Figure 5, A and B). At 2 weeks, a similar reduction in tumor size was observed, although statistical significance at this time point was not achieved. Neutralization of TF also reduced $\mathrm{aPL}^{+}$IgG-mediated tumor vessel density by $60 \%$ compared with size-matched tumors treated with $\mathrm{aPL}^{+} \mathrm{IgG}$ (Figure 5, C and D), suggesting that TF may mediate the protumor effect of aPL by promoting tumor angiogenesis.

Because the TF-neutralizing antibody recognizes both human and murine $\mathrm{TF},{ }^{57}$ the TF dependency we observed potentially reflects a role of tumor cell- or host-derived TF. Host TF has been shown to have minimal impact on tumor growth in multiple murine models, ${ }^{21}$ whereas tumor cell-derived TF has been shown to promote tumor progression in multiple murine cancer models. ${ }^{20,21,58}$ To definitively address the role of tumor cell-derived TF, we used a gene-silencing approach. Lentiviruses carrying four different TF shRNA expression vectors, as well as an empty control vector, were used to infect MDA-MB-436 and
MDA-MB-468 cells. Three of the shRNAs (TFKD321 to 323) were designed to target the TF $3^{\prime}$ untranslated region and one, TFKD 324 , was designed to target exon 2. In pilot experiments, all of the TF-shRNA-expressing cells displayed significant reduction of TF mRNA (Supplemental Figure S4A). We selected two shRNAs, TFKD321 and 324 , for further analysis because of their differences in target site and inhibitory efficiency (approximately 60\% for TFKD321 and $>80 \%$ for TFKD324). Western blot analysis demonstrated a high efficiency of TF knockdown in MDAMB-436 cells carrying either TFKD321 or TFKD324, with only minimal responses to $\mathrm{aPL}^{+} \mathrm{IgG}$ treatment in either knockdown line (Figure 5E). TF knockdown in MDA-MB436 cells did not inhibit cell growth in vitro, and in fact TFknockdown MDA-MB-436 cells showed increased viability by MTT assay (Supplemental Figure S4B). We then tested the effect of TF knockdown in tumor cells on $\mathrm{aPL}^{+} \mathrm{IgG}_{-}$ induced tumor progression in vivo. MDA-MB-436 cells carrying TFKD321, TFKD324, or control vector were coinjected with aPL\#1 IgG into mammary glands. Tumor formation and growth were monitored weekly and confirmed by whole body bioluminescent imaging for GFP, which is expressed by the lentiviral vector in transfected tumor cells (Supplemental Figure S4C). Consistent with our findings using anti-TF-neutralizing antibody, TF knockdown inhibited $\mathrm{aPL}^{+}$IgG-induced tumor progression. Throughout the 3-week period of observation after grafting, tumor sizes in TFKD324-bearing xenografts were reduced $>85 \%$ relative to control $(P=0.012, P<0.001$, and $P=0.004$ for weeks 1, 2, and 3, respectively) (Figure 5F). In xenografts with TFKD321-transduced cells, in which TF knockdown is less efficient, a trend of growth inhibition was observed, reaching approximately 50\% inhibition at 3 weeks, although no statistical significance was achieved (Figure 5F). Consistent with these findings, vessel density in $\mathrm{aPL}^{+}$IgG-treated tumor xenografts containing TFKD324bearing MDA-MB-436 cells was lower than that of $\mathrm{aPL}^{+}$ IgG-treated control tumors (Figure $5 \mathrm{G}$ ).

We next considered potential mechanisms downstream of TF that might mediate $\mathrm{aPL}^{+}$IgG-induced angiogenesis. Full-length TF, the form induced by $\mathrm{aPL}^{+} \mathrm{IgG}$, is an integral membrane protein and may, therefore, act in an autocrine manner to trigger proangiogenic factor production in tumor cells, although it may also potentially be released in microparticles to affect neighboring tumor/ stromal cells in a paracrine manner. ${ }^{59}$ Although it is possible that tumor cell gene expression of VEGF and CSF1 is TF dependent, we have been unable to demonstrate such dependence using neutralizing anti-TF antibodies (data not shown). In contrast, a significant inhibition of CCL2 mRNA expression was observed in both TFKD321 and TFKD324 cells compared with control cells 8 hours after $\mathrm{aPL}^{+}$IgG treatment (Figure $5 \mathrm{H}$ ). The results imply that $\mathrm{aPL}^{+} \mathrm{IgG}$ induces CCL2 production in tumor cells in a TF-dependent manner. These findings are consistent with studies showing that $\mathrm{TF}$ expression in 
endothelial cells can promote angiogenesis via the upregulation of CCL2 expression. ${ }^{60,61}$

One potential mechanism by which CCL2 might mediate $\mathrm{aPL}^{+}$IgG-stimulated angiogenesis is via the recruitment of monocytes/macrophages into tumors. ${ }^{51}$ However, we observed no significant reduction in tumor-associated macrophages on TF depletion, using either TFKD321 or TFKD324 xenografts (data not shown). A second potential mechanism by which CCL2 may promote tumor angiogenesis is via the recruitment of pericytes or vascular smooth muscle cells, which form the mural cells that surround the endothelium in mature blood vessels. These closely related cell types, which both express SMA, are thought to play important supportive roles throughout the process of angiogenesis, ${ }^{62}$ and it has been suggested that the recruitment of these cells to sites of angiogenesis is mediated by the TF-dependent expression of CCL2. ${ }^{60}$ We used fluorescence microscopy to assess $\mathrm{SMA}^{+}$cell association with xenograft tumor vessels in the presence or absence of tumor cell-derived TF. Because TF knockdown reduces vessel density in the xenografts (Figure 5G), we focused the analysis on vessels near the tumor periphery, because vessel density is generally higher in this region relative to the tumor center. Consistent with our IHC studies (Figure 2E), $\mathrm{aPL}^{+}$ IgG-treated xenografts derived from either parental or vector control MDA-MB-436 cells displayed a dense array of vessels with well-developed $\mathrm{SMA}^{+}$mural layers. The SMA in the mural cells of these vessels appeared to be organized as parallel bundles forming a continuous perivascular sheath ${ }^{47}$ (Figure 5I and Supplemental Figure S5, A and D). In contrast, the $\mathrm{SMA}^{+}$mural cell layers in the vessels of $\mathrm{aPL}^{+}$ IgG-treated, TF-deficient tumors were poorly developed, displaying thin bundles of actin stain that did not show parallel organization and typically formed incomplete perivascular sheaths (Figure 5I and Supplemental Figure S5, $\mathrm{B}-\mathrm{F})$. This deficiency in coverage by $\mathrm{SMA}^{+}$cells was evident in both large and small vessels in TF-knockdown compared with control tumors (Supplemental Figure S5). In comparison, vessels in normal mammary tissue adjacent to TF-deficient xenografts displayed well-developed $\mathrm{SMA}^{+}$ mural cell layers similar to those observed in control MDAMB-436 xenografts (Supplemental Figure S5, A and I). The overall density of $\mathrm{SMA}^{+}$intratumoral cells was reduced by $>70 \%$ in TF-knockdown xenografts relative to control xenografts (Supplemental Figure $\mathrm{S} 5 \mathrm{H}$ ). These findings indicate that the incorporation of mural cells during the $\mathrm{aPL}^{+}$ IgG-mediated development of tumor vasculature is dependent on $\mathrm{aPL}^{+} \mathrm{IgG}$-stimulated TF production in tumor cells.

\section{Discussion}

Dormant, microscopic tumors may occur as residual disease after treatment, and may also be prevalent as undiagnosed primary tumors in the general population. ${ }^{1}$ The individual variation with respect to progression of these tumors is potentially due to patient-specific mechanisms, including host characteristics. However, triggering mechanisms that convert precancerous tumors to malignancies are poorly understood, ${ }^{1,63}$ and few patient-specific characteristics have been identified as host factors that promote progression. Herein, we investigated antiphospholipid autoantibodies, which are prevalent in multiple human malignancies, as a potential patient-specific host mechanism promoting tumor progression. Our key findings are that $\mathrm{aPL}^{+} \mathrm{IgG}$ promotes TF-dependent angiogenesis and tumor growth in an orthotopic breast cancer model, accelerates tumor progression in a spontaneous breast cancer model, and stimulates TF expression and the expression of multiple proangiogenic factors in tumor cells (Figure 6). These are the first data to show an effect of these autoantibodies on tumor cells, and, to our knowledge, the first studies to demonstrate tumor

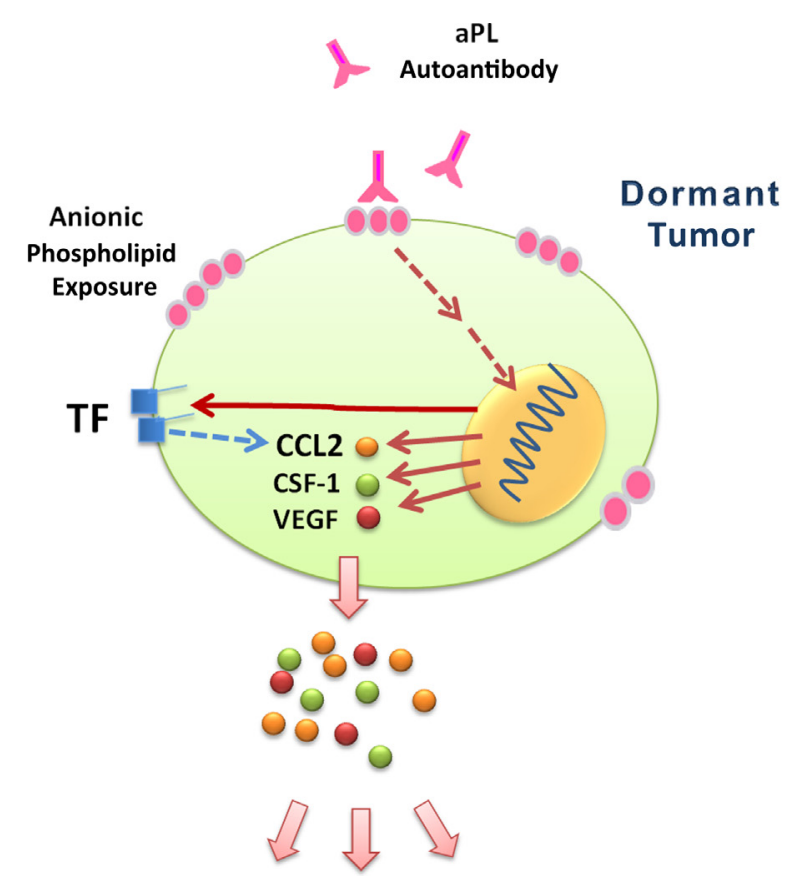

Tumor Stroma: Vasculature Formation and Leukocyte and Fibroblast Recruitment

Angiogenic Switch

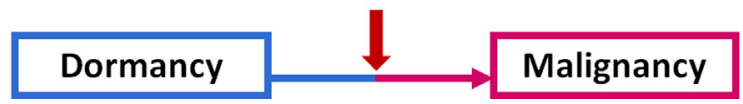

Figure 6 Hypothetical model of antiphospholipid antibodies (aPL)triggered dormancy disruption. Binding of aPL to complexes of phospholipid-binding proteins bound to cell-surface anionic phospholipids on dormant tumor cells induces tumor cell production of proangiogenic factors, including trans-membrane tissue factor (TF) and secretory vascular endothelial growth factor (VEGF) and colony stimulating factor-1 (CSF-1). TF further regulates the production of the chemokine CCL2. These events result in the stimulation of local angiogenic switch and transition of the tumor from dormancy to malignancy. 
growth-accelerating properties in human antibodies. We also present the first data indicating that aPL elevation is not only prevalent in breast cancer, as previously reported in cross-sectional studies of multiple human cancers, ${ }^{10-12}$ but may be specifically associated with invasive stages.

The protumor effect of aPL potentially may involve several mechanisms, including effects on both tumor and host cells. Our observations that $\mathrm{aPL}^{+} \mathrm{IgG}$ stimulates TFdependent angiogenesis in tumors $<1.5 \mathrm{~mm}$ diameter, and that the TF-dependent effect of $\mathrm{aPL}^{+} \mathrm{IgG}$ on tumor growth is detectable within 1 week, suggest that aPL exerts its protumor effect via an early stimulation of tumor angiogenesis. The ability of $\mathrm{aPL}^{+} \mathrm{IgG}$ to trigger proangiogenic gene expression in tumor cells and the dependence of the protumor effect on tumor cell-derived TF argue for a mechanism in which aPL interaction with tumor cells is a key initiating event. Multiple studies report that tumor cells, compared with adjacent normal tissue, express high levels of cell surface anionic phospholipids, ${ }^{4,64,65}$ which form complexes with phospholipid-binding proteins that act as ligands for aPL. ${ }^{2}$ Our findings with respect to tumor annexin A5 content are consistent with these studies. However, activation of monocytes and endothelial cells can also result in phospholipid externalization. ${ }^{3}$ Monocytes exposed to aPL are stimulated to express TF and VEGF. ${ }^{16,18}$ Therefore, although our results implicate aPL-tumor cell interaction as an important mechanism, we cannot rule out a potential contribution of aPL-stromal cell interaction to tumor progression.

Multiple studies indicate a significant contribution of tumor cell-derived TF to tumor progression..$^{21,66,67} \mathrm{TF}$, in the full-length form that we detect, is known to stimulate the expression of several proangiogenic factors in MDA-MB231 cells via intracellular signals initiated by TF cleavage of PAR2 ${ }^{55,68}$ Furthermore, the growth of MDA-MB-231 in the orthotopic model is dependent on TF signaling via PAR2. ${ }^{21,69,70}$ In addition to signaling autologously at the tumor cell surface via PAR2, the proangiogenic function of tumor cell TF may be further dispersed by the release of TFbearing microparticles, which are readily detected in cancer models, ${ }^{71,72}$ and are capable of mediating tumor cell activation of endothelial cells. ${ }^{73}$ Although our results clearly point to tumor cell-derived $\mathrm{TF}$ as an important mediator of aPL protumor effects, the up-regulation by $\mathrm{aPL}^{+} \mathrm{IgG}$ of tumor cell expression of multiple factors indicates the potential involvement of additional mechanisms. Tumor cell-derived CSF1/macrophage-CSF could potentially support the recruitment and activity of tumor-associated macrophages, which we and others have previously shown to play a critical role in the promotion of tumor angiogenesis, invasion, and metastasis. ${ }^{25,27,48,74}$ This idea is consistent with our observation of TF-independent accumulation of macrophages in $\mathrm{aPL}^{+}$IgG-treated tumors, and with the appearance of numerous macrophages in small $\mathrm{aPL}^{+}$ IgG-treated tumors displaying high blood vessel density and invasive phenotype. Another potential proangiogenic mechanism is tumor cell expression of VEGF, which we observed to be increased by $\mathrm{aPL}^{+} \mathrm{IgG}$. Previous studies indicate that tumor cell-derived VEGF may play a critical role in tumor angiogenesis. ${ }^{75,76}$ The aPL-treated orthotopic model is likely to provide a useful system for future dissection of the contributions of these and other proangiogenic factors, because it permits the experimental triggering of angiogenesis in a defined time window via aPL administration.

Previous studies of the stimulation of MDA-MB-231 breast cancer cells via the TF-PAR2 pathway demonstrated the expression of multiple factors that might potentially act as TF effectors mediating tumor angiogenesis, including VEGF, VEGF-C, Cyr6r, connective tissue growth factor, CXCL1, and IL-8. ${ }^{55,68}$ In this study, we additionally identified CCL2 as a TF-dependent factor expressed in $\mathrm{aPL}^{+}$ IgG-treated MDA-MB-436 cells. The significance of these TF-induced molecules as mediators of TF-dependent tumor angiogenesis has not been established. However, recent studies of CCL2 function have shown that, in addition to the well-characterized role of this chemokine as monocyte/ macrophage chemoattractant, CCL2 may also act as a mediator of TF-promoted angiogenesis, via the recruitment of $\mathrm{SMA}^{+}$pericytes/vascular smooth muscle cells. ${ }^{60,61}$ Our findings point to the recruitment of $\mathrm{SMA}^{+}$cells as a potential effector mechanism of aPL-TF-mediated angiogenesis, because the ablation of tumor cell $\mathrm{TF}$, although without noticeable effect on macrophage recruitment, severely affected the intratumoral accumulation of $\mathrm{SMA}^{+}$cells and resulted in the formation of tumor blood vessels with thin and incompletely developed $\mathrm{SMA}^{+}$mural cell layers. These mural cells may support angiogenesis by both enhancing vessel stability and providing paracrine/juxtacrine cues to the underlying endothelial cells. ${ }^{77}$ Our study provides the first demonstration in vivo of a functional link between tumor cell TF and tumor recruitment of these potentially pivotal stromal elements.

The mechanisms by which aPL binds to cell surfaces and initiates signal transduction are not well defined. Studies in monocytes and endothelial cells indicate potential contributions from a variety of cell surface proteins to aPLmediated signaling, including annexin II, low-density lipoprotein receptor-related protein 8 , and several members of the Toll-like receptor (TLR) family (TLR2, TLR4, and TLR8). ${ }^{78}$ Of these molecules, annexin II and TLR4 have been implicated in aPL induction of TF expression in monocytes. ${ }^{18,79}$ Annexin II and TLR4 are both widely expressed in breast cancer, ${ }^{80,81}$ and they have both been shown to be strongly expressed in transcriptomic studies of MDA-MB-436 cells. ${ }^{80,81}$ A recent study showed that tumor angiogenesis in MDA-MB-231 xenografts was dependent on annexin II, ${ }^{80}$ which is strongly associated with advancedstage breast cancer. ${ }^{77}$ Our data demonstrate that MDA-MB231, a much more aggressive tumor than MDA-MB-436 in the orthotopic model, constitutively expresses TF at levels greater than those achieved with $\mathrm{aPL}^{+} \mathrm{IgG}$ stimulation of 
MDA-MB-436. It is conceivable, then, that aPL acts on dormant tumors, represented in our model by MDA-MB436 cells, to activate an annexin II-based pathway of TF expression that is constitutively functional in cell lines, such as MDA-MB-231, that may be representative of advancedstage tumors in which angiogenic switch has taken place. Consistent with this interpretation, we observed no effect of $\mathrm{aPL}^{+} \mathrm{IgG}$ on either MDA-MB-231 or another fast-growing tumor, PC3.

Antiphospholipid autoantibodies include antibodies that recognize several different complexes of phospholipids and phospholipid-binding proteins. Antibodies recognizing complexes of cardiolipin and $\beta 2$-glycoprotein I (anti$\beta 2 \mathrm{GPI})$ are increasingly recognized as the major pathogenic entity in APS, ${ }^{40,41}$ and anti- $\beta 2$ GPI has been strongly linked to the induction of $\mathrm{TF}$ in monocytes in studies using monoclonal or affinity-purified antibodies. ${ }^{82,83} \mathrm{TF}$ induction appears to be a robust property of these antibodies: a recent study of monocyte TF expression in response to $\mathrm{IgG}$ from patients bearing anti- $\beta 2$ GPI observed $>10$-fold stimulation by $\mathrm{IgG}$ from each of eight individuals, in comparison to 12 healthy donors. ${ }^{18}$ Notably, of the 13 patients with invasive breast cancer that we surveyed, $5(38 \%)$ were above cutoff with respect to anti- $\beta 2 \mathrm{GPI}$, and 5 more were between $50 \%$ to $100 \%$ of cutoff (data not shown). Therefore, although it remains possible that aPL in cancer patients will reveal functional differences with respect to protumor effects, compared with aPL from the three non-cancer patients used in this study, the available serological data, both in our and other studies, ${ }^{13,14}$ suggest the potential for aPL activation of TF-mediated angiogenic function in cancer settings. Investigation of protumor function in cancer patient sera will be the subject of future studies.

Antibodies that recognize tumor cells may, in principle, be capable of mediating anti-tumor responses, in addition to the protumor effects we have described. We did not observe anti-tumor effects of aPL in the immunocompetent PyMT model; however, it remains to be determined whether such effects might be observed in other settings. aPL antibodies, purified from APS patient serum, were reported to inhibit metastasis in a murine melanoma model. ${ }^{84}$ However, in human melanoma patients, autoimmune status (including the presence of anticardiolipin antibodies) has not shown any consistent relationship with outcome ${ }^{85,86}$ Bavituximab, a mononclonal antibody recognizing phosphatidylserine and $\beta 2 \mathrm{GPI}$, displays an anti-tumor effect associated with the enhancement of anti-tumor immunity. ${ }^{87}$ The distinct function of bavituximab, compared with $\mathrm{aPL}^{+} \mathrm{IgG}$ in our study, may be due to its distinct specificity. Bavituximab acts through binding to domain II of $\beta 2 \mathrm{GPI},{ }^{88}$ whereas pathogenic human aPL predominantly targets domain I at the N-terminus. ${ }^{89,90}$ Anti-domain I reactivity is strongly correlated with coagulopathy, with respect to both clinical manifestations in patients and in vitro studies of clotting time. ${ }^{90,91}$

The aPL prevalence we and others have documented in cancer patients presumably reflects chronic elevation of these autoantibodies, although this has not been verified by repeated sampling in most studies. However, in addition to chronic elevation, aPL may also become transiently elevated in infections. ${ }^{8,92}$ For example, parvovirus, which has an incidence of $30 \%$ to $60 \%$ in US women, ${ }^{93}$ is associated with elevated levels of anti- $\beta 2 \mathrm{GPI} .{ }^{94}$ In the general population, the frequency of elevated aPL is approximately $1 \% .^{2,7}$ Because an unknown, but potentially large, fraction of these instances represent transient responses, the long-term risk of transient aPL elevation in cancer patients is difficult to determine and may be substantial. Transient aPL has only a limited association with coagulopathy, ${ }^{95}$ perhaps because of the low probability of a coincidence between transient aPL elevation and transient events that generate cell surface targets for the autoantibodies (the two-hit hypothesis ${ }^{96}$ ). In contrast, the findings in this study, as well as earlier reports describing phospholipid exposure in tumor cells, ${ }^{4,43,44}$ indicate that tumors are a potential source of chronically presented aPL targets, and therefore transient aPL responses may potentially be clinically significant in cancer.

It remains difficult to account for the transition of tumors to a proangiogenic, aggressive phenotype. Although multiple studies have identified host pathways, such as the promotion of host cell recruitment and VEGF mobilization by matrix metalloproteinase- $9,{ }^{97-100}$ as important for the promotion of tumor angiogenesis in animal models, there are few studies that can associate this transition with events or characteristics identifiable in patients. It is especially urgent to investigate such factors in breast cancer, in which many deaths are attributed to the transition of residual disease from a dormant to an aggressive state. ${ }^{1,101,102}$ Consequently, we have focused our studies on two cell lines chosen for their promise as potential models of dormancy, and it is notable that we observed effects of $\mathrm{aPL}^{+} \mathrm{IgG}$ only on these lines, and not on lines that display no dormant tendencies. We demonstrated proangiogenic effects of $\mathrm{aPL}^{+} \mathrm{IgG}$ in tumors whose size $(<1.5 \mathrm{~mm}$ diameter $)$ and vascular deficiency are consistent with previous descriptions of a dormant tumor phenotype. ${ }^{103}$ Escape from dormancy may also be a critical process in primary tumor development, as suggested by the estimate that $>20 \%$ of women between the ages of 40 and 50 years have clinically undetectable breast cancer. ${ }^{104}$ Our studies indicate that elevation of patient aPL deserves consideration as a novel factor promoting angiogenic switch. Further studies are needed to assess the clinical significance of this mechanism and to further delineate the pathways linking these autoantibodies to tumor progression in experimental models.

\section{Acknowledgments}

We thank Drs. Betty Diamond, Amy Sue Fox, Jeffrey W. Pollard, Jeffrey Segall, and Jayanta Roy-Chowdhury for useful discussion; the Clinical Immunodiagnostic Laboratory 
and Pathology Core Laboratory at Montefiore Medical Center for technical assistance; Christopher Swain, Elaine Gayle, and Juan Gomez for their consistent effort in patient sample collection; Ernestina Middleton and staff in Immunodiagnostic Laboratory for sample processing; the shRNA Core Facility, Histology and Comparative Pathology Facility, Facility of Animal Studies, Gene Therapy Facility and Analytic Image Facility at Albert Einstein College of Medicine (Bronx, NY) for assistance; Wa Shen, Maya L. Orlofsky, Xia Wang, Jiu-feng Li, Mark Thomson, and Charles Sporn for technical support; Yolanda Cassidy for administrative assistance; and Dr. Jeffrey W. Pollard (Albert Einstein College of Medicine) for kindly providing PyMT mice.

Y.-Y.W. and A.V.N. contributed equally in designing strategies, performing experiments, analyzing data, and preparing the manuscript; X.-X.W., Y.Z., J.H.R., and L.L.M. contributed to the discussions and important ideas in experiment design, trouble shooting, and data analysis; Q.L. and Y.W. contributed clinical data collection and analysis; P.G. performed imaging analysis and confocal microscopy; M.L. and M.V. performed tissue culture and data analysis of IHC; E.Y.L. supervised the study; and A.O., Y.-Y.W., and E.Y.L. wrote the manuscript.

\section{Supplemental Data}

Supplemental material for this article can be found at http://dx.doi.org/10.1016/j.ajpath.2014.07.027.

\section{References}

1. Almog N: Molecular mechanisms underlying tumor dormancy. Cancer Lett 2010, 294:139-146

2. Rand JH: Molecular pathogenesis of the antiphospholipid syndrome. Circ Res 2002, 90:29-37

3. Goth SR, Stephens RS: Rapid, transient phosphatidylserine externalization induced in host cells by infection with Chlamydia spp. Infect Immun 2001, 69:1109-1119

4. Riedl S, Rinner B, Asslaber M, Schaider H, Walzer S, Novak A, Lohner K, Zweytick D: In search of a novel target: phosphatidylserine exposed by non-apoptotic tumor cells and metastases of malignancies with poor treatment efficacy. Biochim Biophys Acta 2011, 1808: 2638-2645

5. Boyle EM Jr, Pohlman TH, Cornejo CJ, Verrier ED: Endothelial cell injury in cardiovascular surgery: ischemia-reperfusion. Ann Thorac Surg 1996, 62:1868-1875

6. Rand JH: The antiphospholipid syndrome. Hematology Am Soc Hematol Educ Program 2007:136-142

7. de Groot PG, Urbanus RT, Derksen RH: Pathophysiology of thrombotic APS: where do we stand? Lupus 2012, 21:704-707

8. Uthman IW, Gharavi AE: Viral infections and antiphospholipid antibodies. Semin Arthritis Rheum 2002, 31:256-263

9. Rojas-Villarraga A, Toro CE, Espinosa G, Rodriguez-Velosa Y, Duarte-Rey C, Mantilla RD, Iglesias-Gamarra A, Cervera R, Anaya JM: Factors influencing polyautoimmunity in systemic lupus erythematosus. Autoimmun Rev 2010, 9:229-232

10. Tincani A, Taraborelli M, Cattaneo R: Antiphospholipid antibodies and malignancies. Autoimmun Rev 2010, 9:200-202
11. Font C, Vidal L, Espinosa G, Tassies D, Monteagudo J, Farrus B, Visa L, Cervera R, Gascon P, Reverter JC: Solid cancer, antiphospholipid antibodies, and venous thromboembolism. Autoimmun Rev 2011, 10:222-227

12. Reinstein E, Shoenfeld Y: Antiphospholipid syndrome and cancer. Clin Rev Allergy Immunol 2007, 32:184-187

13. Endler G, Marsik C, Jilma B, Schickbauer T, Vormittag R, Wagner O, Mannhalter C, Rumpold H, Pabinger I: Anti-cardiolipin antibodies and overall survival in a large cohort: preliminary report. Clin Chem 2006, 52:1040-1044

14. Finazzi G: The Italian Registry of Antiphospholipid Antibodies Haematologica 1997, 82:101-105

15. Satta N, Kruithof EK, Fickentscher C, Dunoyer-Geindre S, Boehlen F, Reber G, Burger D, de Moerloose P: Toll-like receptor 2 mediates the activation of human monocytes and endothelial cells by antiphospholipid antibodies. Blood 2011, 117:5523-5531

16. Cuadrado MJ, Buendia P, Velasco F, Aguirre MA, Barbarroja N, Torres LA, Khamashta M, Lopez-Pedrera C: Vascular endothelial growth factor expression in monocytes from patients with primary antiphospholipid syndrome. J Thromb Haemost 2006, 4:2461-2469

17. Williams FM, Parmar K, Hughes GR, Hunt BJ: Systemic endothelial cell markers in primary antiphospholipid syndrome. Thromb Haemost 2000, 84:742-746

18. Motoki $\mathrm{Y}$, Nojima J, Yanagihara M, Tsuneoka H, Matsui $\mathrm{T}$, Yamamoto M, Ichihara K: Anti-phospholipid antibodies contribute to arteriosclerosis in patients with systemic lupus erythematosus through induction of tissue factor expression and cytokine production from peripheral blood mononuclear cells. Thromb Res 2012, 130:667-673

19. Mackman N, Davis GE: Blood coagulation and blood vessel development: is tissue factor the missing link? Arterioscler Thromb Vasc Biol 2011, 31:2364-2366

20. Kasthuri RS, Taubman MB, Mackman N: Role of tissue factor in cancer. J Clin Oncol 2009, 27:4834-4838

21. Schaffner F, Yokota N, Ruf W: Tissue factor proangiogenic signaling in cancer progression. Thromb Res 2012, 129(Suppl 1):S127-S131

22. Miyakis S, Lockshin MD, Atsumi T, Branch DW, Brey RL, Cervera R, Derksen RH, DE Groot PG, Koike T, Meroni PL, Reber G, Shoenfeld Y, Tincani A, Vlachoyiannopoulos PG, Krilis SA: International consensus statement on an update of the classification criteria for definite antiphospholipid syndrome (APS). J Thromb Haemost 2006, 4:295-306

23. Rand JH, Wu XX, Quinn AS, Ashton AW, Chen PP, Hathcock JJ, Andree HA, Taatjes DJ: Hydroxychloroquine protects the annexin A5 anticoagulant shield from disruption by antiphospholipid antibodies: evidence for a novel effect for an old antimalarial drug. Blood 2010, 115:2292-2299

24. Donohoe S, Kingdom JC, Mackie IJ: Affinity purified human antiphospholipid antibodies bind normal term placenta. Lupus 1999, 8 525-531

25. Lin EY, Nguyen AV, Russell RG, Pollard JW: Colony-stimulating factor 1 promotes progression of mammary tumors to malignancy. J Exp Med 2001, 193:727-740

26. Lin EY, Jones JG, Li P, Zhu L, Whitney KD, Muller WJ, Pollard JW: Progression to malignancy in the polyoma middle $\mathrm{T}$ oncoprotein mouse breast cancer model provides a reliable model for human diseases. Am J Pathol 2003, 163:2113-2126

27. Lin EY, Li JF, Gnatovskiy L, Deng Y, Zhu L, Grzesik DA, Qian H, Xue XN, Pollard JW: Macrophages regulate the angiogenic switch in a mouse model of breast cancer. Cancer Res 2006, 66:11238-11246

28. Rand JH, Wu XX, Guller S, Gil J, Guha A, Scher J, Lockwood CJ: Reduction of annexin- $\mathrm{V}$ (placental anticoagulant protein-I) on placental villi of women with antiphospholipid antibodies and recurrent spontaneous abortion. Am J Obstet Gynecol 1994, 171: $1566-1572$

29. Luong TH, Rand JH, Wu XX, Godbold JH, Gascon-Lema M, Tuhrim S: Seasonal distribution of antiphospholipid antibodies. Stroke 2001, 32:1707-1711 
30. Naumov GN, Bender E, Zurakowski D, Kang SY, Sampson D, Flynn E, Watnick RS, Straume O, Akslen LA, Folkman J, Almog N: A model of human tumor dormancy: an angiogenic switch from the nonangiogenic phenotype. J Natl Cancer Inst 2006, 98:316-325

31. Vantyghem SA, Allan AL, Postenka CO, Al-Katib W, Keeney M, Tuck AB, Chambers AF: A new model for lymphatic metastasis: development of a variant of the MDA-MB-468 human breast cancer cell line that aggressively metastasizes to lymph nodes. Clin Exp Metastasis 2005, 22:351-361

32. Naumov GN, Akslen LA, Folkman J: Role of angiogenesis in human tumor dormancy: animal models of the angiogenic switch. Cell Cycle 2006, 5:1779-1787

33. Beenhouwer DO, Yoo EM, Lai CW, Rocha MA, Morrison SL: Human immunoglobulin $\mathrm{G} 2$ ( $\operatorname{IgG} 2$ ) and $\operatorname{IgG} 4$, but not $\operatorname{IgG} 1$ or $\operatorname{IgG} 3$, protect mice against Cryptococcus neoformans infection. Infect Immun 2007, 75:1424-1435

34. Vaccaro C, Bawdon R, Wanjie S, Ober RJ, Ward ES: Divergent activities of an engineered antibody in murine and human systems have implications for therapeutic antibodies. Proc Natl Acad Sci U S A 2006, 103:18709-18714

35. Guerin J, Casey E, Feighery C, Jackson J: Anti-Beta 2-glycoprotein I antibody isotype and $\operatorname{IgG}$ subclass in antiphospholipid syndrome patients. Autoimmunity 1999, 31:109-116

36. Dostal-Johnson D, Rote NS, Branch DW: IgG1 and IgG2 are the predominant subclasses of antiphospholipid antibody in women with the lupus anticoagulant. Clin Immunol Immunopathol 1990, 54: 309-319

37. Arad A, Proulle V, Furie RA, Furie BC, Furie B: beta(2)-Glycoprotein-1 autoantibodies from patients with antiphospholipid syndrome are sufficient to potentiate arterial thrombus formation in a mouse model. Blood 2011, 117:3453-3459

38. Fischetti F, Durigutto P, Pellis V, Debeus A, Macor P, Bulla R, Bossi F, Ziller F, Sblattero D, Meroni P, Tedesco F: Thrombus formation induced by antibodies to beta2-glycoprotein I is complement dependent and requires a priming factor. Blood 2005, 106:2340-2346

39. de la Torre YM, Pregnolato F, D'Amelio F, Grossi C, Di Simone N, Pasqualini F, Nebuloni M, Chen P, Pierangeli S, Bassani N, Ambrogi F, Borghi MO, Vecchi A, Locati M, Meroni PL: Antiphospholipid induced murine fetal loss: novel protective effect of a peptide targeting the beta2 glycoprotein I phospholipid-binding site: implications for human fetal loss. J Autoimmun 2012, 38:J209-J215

40. Willis R, Pierangeli SS: Anti-beta2-glycoprotein I antibodies. Ann N Y Acad Sci 2013, 1285:44-58

41. Giannakopoulos B, Mirarabshahi P, Krilis SA: New insights into the biology and pathobiology of beta2-glycoprotein I. Curr Rheumatol Rep 2011, 13:90-95

42. Agar C, de Groot PG, Marquart JA, Meijers JC: Evolutionary conservation of the lipopolysaccharide binding site of beta(2)glycoprotein I. Thromb Haemost 2011, 106:1069-1075

43. Sugimura M, Donato R, Kakkar VV, Scully MF: Annexin V as a probe of the contribution of anionic phospholipids to the procoagulant activity of tumour cell surfaces. Blood Coagul Fibrinolysis 1994, 5: 365-373

44. Utsugi T, Schroit AJ, Connor J, Bucana CD, Fidler IJ: Elevated expression of phosphatidylserine in the outer membrane leaflet of human tumor cells and recognition by activated human blood monocytes. Cancer Res 1991, 51:3062-3066

45. Rand JH, Wu XX, Quinn AS, Taatjes DJ: The annexin A5-mediated pathogenic mechanism in the antiphospholipid syndrome: role in pregnancy losses and thrombosis. Lupus 2010, 19:460-469

46. Naumov GN, Folkman J, Straume O: Tumor dormancy due to failure of angiogenesis: role of the microenvironment. Clin Exp Metastasis 2009, 26:51-60

47. Wallow $\mathrm{IH}$, Burnside B: Actin filaments in retinal pericytes and endothelial cells. Invest Ophthalmol Vis Sci 1980, 19:1433-1441

48. Newman AC, Hughes CC: Macrophages and angiogenesis: a role for Wnt signaling. Vasc Cell 2012, 4:13
49. Pierangeli SS, Chen PP, Raschi E, Scurati S, Grossi C, Borghi MO, Palomo I, Harris EN, Meroni PL: Antiphospholipid antibodies and the antiphospholipid syndrome: pathogenic mechanisms. Semin Thromb Hemost 2008, 34:236-250

50. Chambers SK: Role of CSF-1 in progression of epithelial ovarian cancer. Future Oncol 2009, 5:1429-1440

51. Soria G, Ben-Baruch A: The inflammatory chemokines CCL2 and CCL5 in breast cancer. Cancer Lett 2008, 267:271-285

52. Salcedo R, Ponce ML, Young HA, Wasserman K, Ward JM, Kleinman HK, Oppenheim JJ, Murphy WJ: Human endothelial cells express CCR2 and respond to MCP-1: direct role of MCP-1 in angiogenesis and tumor progression. Blood 2000, 96:34-40

53. Gazzaniga S, Bravo AI, Guglielmotti A, van Rooijen N, Maschi F, Vecchi A, Mantovani A, Mordoh J, Wainstok R: Targeting tumorassociated macrophages and inhibition of MCP-1 reduce angiogenesis and tumor growth in a human melanoma xenograft. J Invest Dermatol 2007, 127:2031-2041

54. Butenas S: Comparison of natural and recombinant tissue factor proteins: new insights. Biol Chem 2013, 394:819-829

55. Albrektsen T, Sorensen BB, Hjorto GM, Fleckner J, Rao LV, Petersen LC: Transcriptional program induced by factor VIIa-tissue factor, PAR1 and PAR2 in MDA-MB-231 cells. J Thromb Haemost 2007, 5:1588-1597

56. Speidel CM, Eisenberg PR, Ruf W, Edgington TS, Abendschein DR: Tissue factor mediates prolonged procoagulant activity on the luminal surface of balloon-injured aortas in rabbits. Circulation 1995, 92: $3323-3330$

57. Parry GC, Erlich JH, Carmeliet P, Luther T, Mackman N: Low levels of tissue factor are compatible with development and hemostasis in mice. J Clin Invest 1998, 101:560-569

58. Versteeg HH, Schaffner F, Kerver M, Petersen HH, Ahamed J, Felding-Habermann B, Takada Y, Mueller BM, Ruf W: Inhibition of tissue factor signaling suppresses tumor growth. Blood 2008, 111:190-199

59. Rak J, Milsom C, Yu J: Tissue factor in cancer. Curr Opin Hematol 2008, 15:522-528

60. Arderiu G, Pena E, Aledo R, Juan-Babot O, Badimon L: Tissue factor regulates microvessel formation and stabilization by induction of chemokine (C-C motif) ligand 2 expression. Arterioscler Thromb Vasc Biol 2011, 31:2607-2615

61. Arderiu G, Pena E, Aledo R, Espinosa S, Badimon L: Ets-1 transcription is required in tissue factor driven microvessel formation and stabilization. Angiogenesis 2012, 15:657-669

62. Raza A, Franklin MJ, Dudek AZ: Pericytes and vessel maturation during tumor angiogenesis and metastasis. Am J Hematol 2010, 85: 593-598

63. Gelao L, Criscitiello C, Fumagalli L, Locatelli M, Manunta S, Esposito A, Minchella I, Goldhirsch A, Curigliano G: Tumour dormancy and clinical implications in breast cancer. Ecancermedicalscience 2013, 7:320

64. Yan X, Doffek K, Yin C, Krein M, Phillips M, Sugg SL, Johnson B, Shilyansky J: Annexin-V promotes anti-tumor immunity and inhibits neuroblastoma growth in vivo. Cancer Immunol Immunother 2012, 61:1917-1927

65. Woehlecke H, Pohl A, Alder-Baerens N, Lage H, Herrmann A: Enhanced exposure of phosphatidylserine in human gastric carcinoma cells overexpressing the half-size ABC transporter BCRP (ABCG2). Biochem J 2003, 376:489-495

66. Magnus N, Garnier D, Meehan B, McGraw S, Lee TH, Caron M, Bourque G, Milsom C, Jabado N, Trasler J, Pawlinski R, Mackman N, Rak J: Tissue factor expression provokes escape from tumor dormancy and leads to genomic alterations. Proc Natl Acad Sci U S A 2014, 111:3544-3549

67. van den Berg YW, Osanto S, Reitsma PH, Versteeg HH: The relationship between tissue factor and cancer progression: insights from bench and bedside. Blood 2012, 119:924-932

68. Hjortoe GM, Petersen LC, Albrektsen T, Sorensen BB, Norby PL, Mandal SK, Pendurthi UR, Rao LV: Tissue factor-factor 
VIIa-specific up-regulation of IL-8 expression in MDA-MB-231 cells is mediated by PAR-2 and results in increased cell migration. Blood 2004, 103:3029-3037

69. Ruf W: Tissue factor and cancer. Thromb Res 2012, 130(Suppl 1): S84-S87

70. Ryden L, Grabau D, Schaffner F, Jonsson PE, Ruf W, Belting M: Evidence for tissue factor phosphorylation and its correlation with protease-activated receptor expression and the prognosis of primary breast cancer. Int J Cancer 2010, 126:2330-2340

71. Zwicker JI, Liebman HA, Neuberg D, Lacroix R, Bauer KA, Furie BC, Furie B: Tumor-derived tissue factor-bearing microparticles are associated with venous thromboembolic events in malignancy. Clin Cancer Res 2009, 15:6830-6840

72. Davila M, Amirkhosravi A, Coll E, Desai H, Robles L, Colon J, Baker $\mathrm{CH}$, Francis JL: Tissue factor-bearing microparticles derived from tumor cells: impact on coagulation activation. J Thromb Haemost 2008, 6:1517-1524

73. Svensson KJ, Kucharzewska P, Christianson HC, Skold S, Lofstedt T, Johansson MC, Morgelin M, Bengzon J, Ruf W, Belting M: Hypoxia triggers a proangiogenic pathway involving cancer cell microvesicles and PAR-2-mediated heparin-binding EGF signaling in endothelial cells. Proc Natl Acad Sci U S A 2011, 108:13147-13152

74. Obeid E, Nanda R, Fu YX, Olopade OI: The role of tumor-associated macrophages in breast cancer progression (review). Int J Oncol 2013, 43:5-12

75. Grunstein J, Roberts WG, Mathieu-Costello O, Hanahan D, Johnson RS: Tumor-derived expression of vascular endothelial growth factor is a critical factor in tumor expansion and vascular function. Cancer Res 1999, 59:1592-1598

76. Sitohy B, Nagy JA, Dvorak HF: Anti-VEGF/VEGFR therapy for cancer: reassessing the target. Cancer Res 2012, 72:1909-1914

77. Sharma MR, Koltowski L, Ownbey RT, Tuszynski GP, Sharma MC: Angiogenesis-associated protein annexin II in breast cancer: selective expression in invasive breast cancer and contribution to tumor invasion and progression. Exp Mol Pathol 2006, 81:146-156

78. de Groot PG, Raschi E, McCrae KR, Pierangeli SS, Vlachoyiannopoulos PG, Urbanus RT: What are the target cells and receptors that are recognized by antiphospholipid antibodies. Edited by Erkan D, Pierangeli SS. Antiphospholipid Syndrome. Springer US (Springer Healthcare LLC, New York, NY), 2012, pp 103-113

79. Poulton K, Rahman A, Giles I: Examining how antiphospholipid antibodies activate intracellular signaling pathways: a systematic review. Semin Arthritis Rheum 2012, 41:720-736

80. Chuthapisith S, Bean BE, Cowley G, Eremin JM, Samphao S, Layfield R, Kerr ID, Wiseman J, El-Sheemy M, Sreenivasan T, Eremin O: Annexins in human breast cancer: possible predictors of pathological response to neoadjuvant chemotherapy. Eur J Cancer 2009, 45:1274-1281

81. Petricevic B, Vrbanec D, Jakic-Razumovic J, Brcic I, Rabic D, Badovinac T, Ozimec E, Bali V: Expression of Toll-like receptor 4 and beta 1 integrin in breast cancer. Med Oncol 2012, 29:486-494

82. Sorice M, Longo A, Capozzi A, Garofalo T, Misasi R, Alessandri C, Conti F, Buttari B, Rigano R, Ortona E, Valesini G: Anti-beta2glycoprotein I antibodies induce monocyte release of tumor necrosis factor alpha and tissue factor by signal transduction pathways involving lipid rafts. Arthritis Rheum 2007, 56:2687-2697

83. Xie H, Zhou H, Wang H, Chen D, Xia L, Wang T, Yan J: Antibeta(2)GPI/beta(2)GPI induced TF and TNF-alpha expression in monocytes involving both TLR4/MyD88 and TLR4/TRIF signaling pathways. Mol Immunol 2013, 53:246-254

84. Fishman P, Merimsky O, Shoenfeld Y: Autoimmunity and cancer: beneficial relationships. Int J Oncol 1997, 10:901-904

85. Becker JC, Winkler B, Klingert S, Brocker EB: Antiphospholipid syndrome associated with immunotherapy for patients with melanoma. Cancer 1994, 73:1621-1624

86. Bouwhuis MG, Suciu S, Collette S, Aamdal S, Kruit WH, Bastholt L, Stierner U, Sales F, Patel P, Punt CJ, Hernberg M, Spatz A, ten
Hagen TL, Hansson J, Eggermont AM; EORTC Melanoma Group and the Nordic Melanoma Group: Autoimmune antibodies and recurrence-free interval in melanoma patients treated with adjuvant interferon. J Natl Cancer Inst 2009, 101:869-877

87. DeRose P, Thorpe PE, Gerber DE: Development of bavituximab, a vascular targeting agent with immune-modulating properties, for lung cancer treatment. Immunotherapy 2011, 3:933-944

88. Luster TA, He J, Huang X, Maiti SN, Schroit AJ, de Groot PG, Thorpe PE: Plasma protein beta-2-glycoprotein 1 mediates interaction between the anti-tumor monoclonal antibody $3 \mathrm{G} 4$ and anionic phospholipids on endothelial cells. J Biol Chem 2006, 281: 29863-29871

89. Ioannou Y: The Michael Mason Prize: pathogenic antiphospholipid antibodies, stressed out antigens and the deployment of decoys. Rheumatology 2012, 51:32-36

90. Chighizola CB, Gerosa M, Meroni PL: New tests to detect antiphospholipid antibodies: anti-domain I beta-2-glycoprotein-I antibodies. Curr Rheumatol Rep 2014, 16:402

91. de Laat B, van Berkel M, Urbanus RT, Siregar B, de Groot PG, Gebbink MF, Maas C: Immune responses against domain I of beta(2)-glycoprotein I are driven by conformational changes: domain I of beta(2)-glycoprotein I harbors a cryptic immunogenic epitope. Arthritis Rheum 2011, 63:3960-3968

92. Garcia-Carrasco M, Galarza-Maldonado C, Mendoza-Pinto C, Escarcega RO, Cervera R: Infections and the antiphospholipid syndrome. Clin Rev Allergy Immunol 2009, 36:104-108

93. Gratacos E, Torres PJ, Vidal J, Antolin E, Costa J, Jimenez de Anta MT, Cararach V, Alonso PL, Fortuny A: The incidence of human parvovirus B19 infection during pregnancy and its impact on perinatal outcome. J Infect Dis 1995, 171:1360-1363

94. Loizou S, Cazabon JK, Walport MJ, Tait D, So AK: Similarities of specificity and cofactor dependence in serum antiphospholipid antibodies from patients with human parvovirus B19 infection and from those with systemic lupus erythematosus. Arthritis Rheum 1997, 40: $103-108$

95. Avcin T, Toplak N: Antiphospholipid antibodies in response to infection. Curr Rheumatol Rep 2007, 9:212-218

96. Meroni PL, Riboldi P: Pathogenic mechanisms mediating antiphospholipid syndrome. Curr Opin Rheumatol 2001, 13:377-382

97. Chantrain CF, Henriet P, Jodele S, Emonard H, Feron O, Courtoy PJ, DeClerck YA, Marbaix E: Mechanisms of pericyte recruitment in tumour angiogenesis: a new role for metalloproteinases. Eur J Cancer 2006, 42:310-318

98. Chantrain CF, Shimada H, Jodele S, Groshen S, Ye W, Shalinsky DR, Werb Z, Coussens LM, DeClerck YA: Stromal matrix metalloproteinase-9 regulates the vascular architecture in neuroblastoma by promoting pericyte recruitment. Cancer Res 2004, 64: $1675-1686$

99. Jodele S, Chantrain CF, Blavier L, Lutzko C, Crooks GM, Shimada H, Coussens LM, Declerck YA: The contribution of bone marrow-derived cells to the tumor vasculature in neuroblastoma is matrix metalloproteinase-9 dependent. Cancer Res 2005, 65 $3200-3208$

100. Bergers G, Brekken R, McMahon G, Vu TH, Itoh T, Tamaki K, Tanzawa K, Thorpe P, Itohara S, Werb Z, Hanahan D: Matrix metalloproteinase-9 triggers the angiogenic switch during carcinogenesis. Nat Cell Biol 2000, 2:737-744

101. Quesnel B: Dormant tumor cells as a therapeutic target? Cancer Lett 2008, 267:10-17

102. Wells A, Griffith L, Wells JZ, Taylor DP: The dormancy dilemma: quiescence versus balanced proliferation. Cancer Res 2013, 73: $3811-3816$

103. Naumov GN, Folkman J, Straume O, Akslen LA: Tumor-vascular interactions and tumor dormancy. APMIS 2008, 116:569-585

104. Nielsen M, Thomsen JL, Primdahl S, Dyreborg U, Andersen JA: Breast cancer and atypia among young and middle-aged women: a study of 110 medicolegal autopsies. Br J Cancer 1987, 56:814-819 